\title{
PETROLOGY OF THE ZONED, PERALUMINOUS HALIFAX PLUTON, SOUTH-CENTRAL NOVA SCOTIA
}

\author{
M.A. MacDonald and $R . J$. Horne \\ Nova Scotia Department of Mines and Energy \\ P.O. Box 1087, Halifax, Nova Scotia B3J $2 \times 1$ \\ Date Received October 16, 1987 \\ Date Accepted April 8, 1988
}

\begin{abstract}
The Halifax Pluton (HP) is a large (approximately $900 \mathrm{~km}^{2}$ ), discrete plutonic body which forms the southeastern end of the South Mountain Batholith (SMB). The HP comprises a zoned sequence of rock units into which a second. generally more evolved sequence of rocks was intruded. Rocks of the zoned sequence are predominantly medium- to coarse-grained. have megacrystic textures, are generally monzogranitic in composition (with minor granodiorite) and have biotite (415\%), muscovite (trace-4\%) and cordierite (0->4\%) as essential constituents. The second sequence is primarily fineto medium-grained with highly variable textures (e.g., porphyritic, equigranular, graphic), is generally monzogranitic in composition with minor leucogranite ( $<2 \%$ mafic minerals) and syenogranite, and have muscovite (2-10\%). biotite ( $0-$ $8 \%)$ and cordierite $(0-2 \%)$ as essential minerals. Andalusite, generally absent from the zoned sequence, is commonly
\end{abstract} present as an accessory phase. Contacts between the two sequences are invariably intrusive.

Petrographic and geochemical evidence suggests that the outer segment of the zoned sequence is normally zoned ( $1 . e .$. more evolved toward the core). This may be explained by sidewall crystallization in a magma chamber with the removal of plagioclase and biotite (with accessory zircon, monazite, xenotime, apatite and ilmenite). Conversely, the inner portion of the pluton is reversely zoned (1.e.. less evolved toward core with an increase in biotite) which cannot be explained by fractional crystallization. Therefore, a model involving vertical stratification in the melt is proposed.

The presence of the zoned arrangement of rock units coupled with high.contents of $\mathrm{MgO}_{2} \mathrm{P}_{2} \mathrm{O}_{5}$ and normative corundum, enstatite, hypersthene, apatite and high modal amounts of cordierite compared with the central SMB suggest that the HP evolved as a discrete pluton.

Le pluton de Halifax ( $\mathrm{PH}$ ) est un bâti plutonique distinct de grande taille (environ $900 \mathrm{~km}^{2}$ ) qui constitue 1 'extrèmité sud-est du Batholite de South Mountain (BSM). Le PH comprend une sèrie d'unités rocheuses zonée à travers laquelle s'est injecté une seconde serie de roches generalement plus evoluée. Les termes de la série zoné montrent surtout un grain intermediaire à grossier ainsi que des textures mégacristes et ont géneralement une composition monzogranitique (avec quelque granodiorite). Les constituants essentiels en sont la biotite (4-15\%). la muscovite (trace 4\%) et la cordiérite $(0->4 \%)$. La seconde serie presente un grain surtout fin a intermediaire, exhibe des textures varièes (e.g., porphirique, grenue, graphique) et possêde une composition généralement monzogranitique avec quelque leucogranite (minèraux mafiques $2 \%$ ) et spénogranite. Ses minéraux essentiels sont la muscovite (2-10\%). 1a biotite $(0-8 \%)$ et la cordierite $(0-2 \%)$. Bien que generalement absente de la serie zonee. 1 'andalousite forme communement une phase accessoire. Les contacts entre les deux séries sont invarlablement intrusifs.

A la lumière de la pétrographie et la gèochimie, le liseré de la série zonée semble zoné normalement (1.e., plus evolue vers le coeur). Ceci peut s'expliquer par la cristallisation des épontes de la chambre magmatique et l'elimination du plagioclase et de la biotite (avec les zircon, monazite, xenotime, apatite et 1lmenite). Par contre, la portion interne du pluton montre une zonation inverse (i.e.. moins évoluee vers le coeur avec une augmentation de la biotite) qui ne peut s'expliquer par la cristallisation fractionnee. On propose donc un modele necessitant une stratification verticale du bain.

La présence d'une zonation des unités rocheuses combinè aux contenus élevés de $\mathrm{M}_{0} \mathrm{O}_{2} \mathrm{P}_{2} \mathrm{O}_{5}$. corindon normatif enstatite, hypersthene, apatite ainsi qu'aux valeurs modales elevees de la cordierike, par'rapport a la portion centrale du BSM suggerent que le $\mathrm{PH}$ a evolue en tant que pluton distinct.

[Traduit par le journal]

\section{INTRODUCTION}

The South Mountain Batholith (SMB), one of the largest granitoid bodies in the Appalachian Orogen, has received much attention during the past 15 years (Cormier and Smith, 1973; Smith, 1974, 1975, 1979; McKenzie and Clarke, 1975; Chatterjee and Muecke, 1982; Clarke and Muecke, 1985). Recent mapping of the Halifax-St. Margaret's Bay area has revealed some fundamentally important petrological features which had previously received only cursory attention. For example, this work has revealed that this segment of the batholith is composed of a complexiy zoned suite of granitoid rocks characterized by their strongly peraluminous nature. The zonation of this intrusion, high contents of $\mathrm{P}_{2} \mathrm{O}_{5}, \mathrm{MgO}$ and normative corundum, and the high modal percentage of cordierite compared to MARITIME SEDIMENTS AND ATLANTIC GEOLOGY 24. 33-45 (1988) published data for the rest of the batholith suggest that the Halifax Pluton (HP) may have evolved as a separate pluton within the SMB.

It is generally agreed, based on whole rock geochemistry and $\mathrm{Sr}$ and 0 isotope studies, that the SMB was generated by partial melting of a crustal protolith (sedimentary?) (Fairbairn et al., 1964; Smith, 1979; Smith et al., 1982; Longstaffe et al., 1980; Clarke and Halliday, 1980; Halliday et al., 1981; Clarke and Muecke, 1985; Smith et al., 1986). There is also general agreement that the most important petrogenetic mechanism in the SMB was fractional crystallization involving biotite (and included accessories) and plagloclase followed by alkali feldspar, quartz and muscovite(?) (Smith. 1974, 1979; McKenzie and Clarke, 1975; Clarke anc Muecke, 1985; and Smith et al., 1982, 1986). Post-dating crystallization of the SMB, there 
ensued a period of widespread deuteric alteration that was confined primarily to the two-mica monzogranite units (Smith et al., 1982, 1986). However, there is some debate regarding the overall petrogenetic history of the SMB. McKenzie and Clarke (1975), Charest et al. (1985) and Clarke and Muecke (1985) suggested that the entire SMB represents a single co-magmatic suite in which the monzogranitic and leucogranitic rocks were fractionated from, and auto-intruded into, a parental envelope of granodiorite. Conversely, Smith and Turek (1976) and Smith (1979) proposed that each of the monzogranite plutons is unique, with its own independent crystallization history. In this latter scenario the SMB represents a composite batholith formed by the coalescing of small discrete plutons.

The occurrence of both normal and reverse zonation within granitold plutons has been well documented over the past two decades (e.g., Karner, 1968; Ermanovics, 1970; Halliday et al., 1980; Rice, 1981; Ludington, 1981; Ayuso, 1986; Baker and McBirney, 1986; Bourne and Danis, 1987). Mechanisms which have been evoked to explain the zoning have included thermogravitational diffusion (TGD), convective fractionation, fractional crystallization, multiple intrusion, hybridization, and flow differentiation. Most explanations suggested have involved one or more of the above processes.

The purpose of this paper is to address the petrogenetic history of the HP and propose a model for its formation which is consistent with all known field and chemical evidence.

\section{REGIONAL GEOLOGICAL SETTING}

The SMB, located within the Meguma Zone (Fig. 1) of the Appalachian Orogen, is a post-tectonic granitold complex of Devono-Carboniferous age (circa $370-360 \mathrm{Ma}$ ) as determined by $\mathrm{Rb}-\mathrm{Sr}$ (Fairbairn et al., 1964; Clarke and Halliday, 1980) and $\mathrm{K}-\mathrm{Ar}$ and $\mathrm{Ar}-\mathrm{Ar}$ (Reynolds et al., 1981, 1987) dating techniques. The batholith intruded regionally metamorphosed and deformed rocks of the Cambro-Ordovician Meguma Group and the overlying Siluro-Devonian White Rock and Torbrook Formations. The former is comprised of Goldenville Formation metapsammites and overlying Halifax Formation metapelites, whereas the latter comprises mixed volcanic, volcaniclastic and metasedimentary rocks. The SMB is overlain by coarse clastic terrestrial sedimentary rocks of the Horton Group of Tournaissian age (Be11 and Blenkinsop, 1960; Howle and Barss, 1975). Thus, the SMB must have been intruded, unroofed and deposited upon within a very short period of time (i.e., $10 \mathrm{Ma}$ ).

The SMB is peraluminous and is composed of a series of granodiorite-monzogranite-leucogranite units. Recent mapping in the eastern half of the SMB (MacDonald et al., 1987) indicates that the batholith contains approximately 20 major monzogranitic and granodioritic units (generaliy $\left.10-100 \mathrm{~km}^{2}\right)$ and approximately 50 smaller $\left(<1-5 \mathrm{~km}^{2}\right)$ leucomonzogranites (2-6\% total mafics) and leucogranites ( $<2 \%$ total mafics). Contacts between units are both gradational and intrusive, which, when coupled with the large number of units, indicates a complex history of emplacement. There

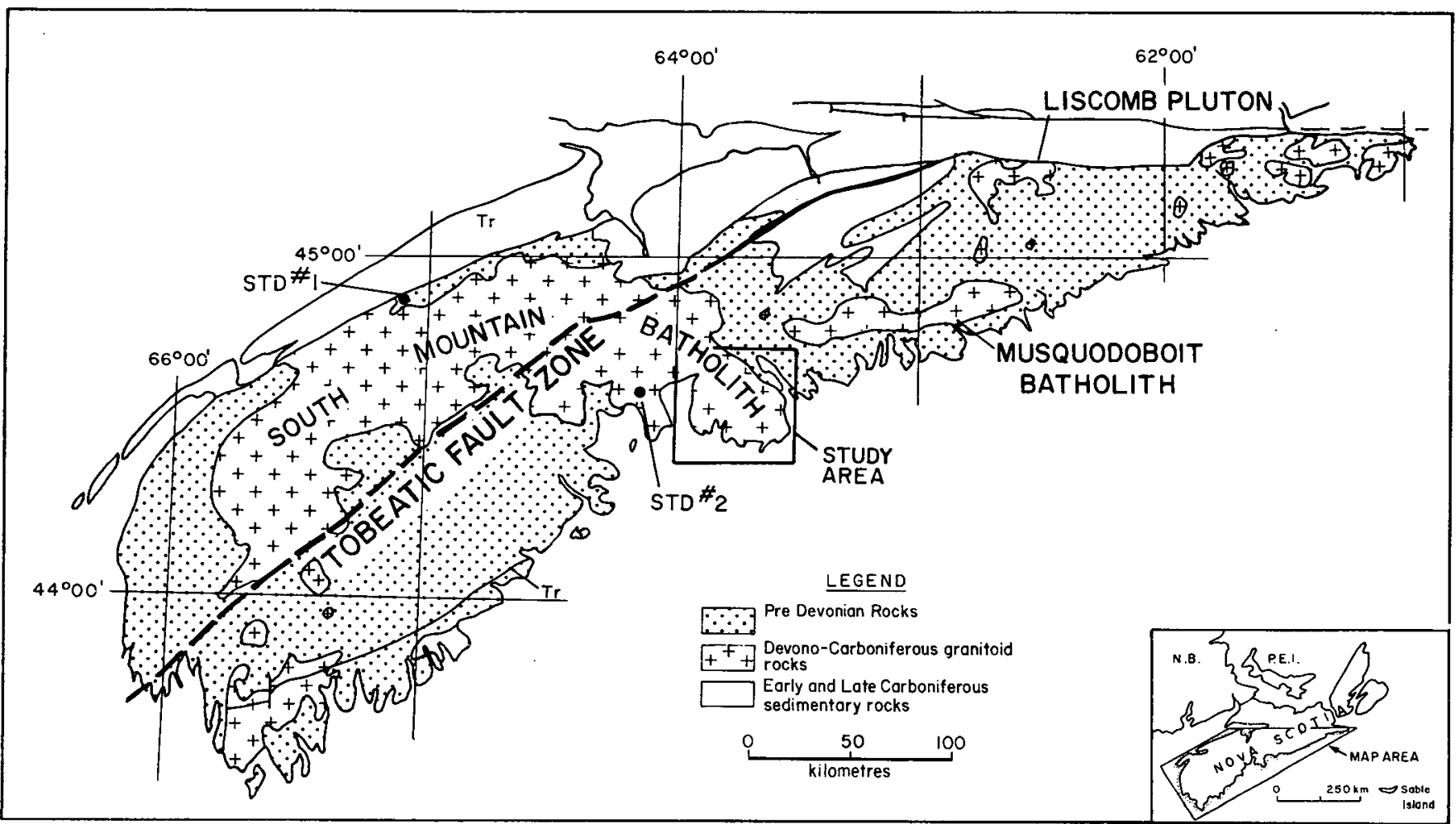

Fig. 1. Location map for the study area, South Mounta1n Batholith and Musquodobolt Batholith. Note the position of the Tobeatic Fault Zone of Giles (1985). Also note the location of the two bench standards from Table 2. 
are discrete plutonic centres within the SMB (e.g., the HP) which have their own crystallization history and unique chemical and mineralogical characteristics (Smith, 1979; MacDonald et al., 1987). This suggests that the SMB did not crystallize from a single parental melt but instead is composite in nature.

The present surface map of the SMB indicates a roughly arcuate shape for the intrusion (Fig. 1). However, in the reconstruction of the Meguma Zone by Giles (1985) the batholith would have been elliptical at the time of emplacement. This reconstruction restores approximately $110 \mathrm{~km}$ of sinistral movement along the proposed post-Visean, pre-Triassic Tobeatic Fault Zone.

\section{GEOLOGY OF THE HALIFAX PENINSULA}

\section{Field Relationships}

\section{Exocontact}

The granitic rocks of the HP display sharp, steep $\left(>70^{\circ}\right)$, discordant contacts with the host metasedimentary rocks of the Meguma Group. Very 1ittle 1it-par-1it injection of dike material into the surrounding metasedimentary rocks is observed.

Hornblende-hornfels facies metamorphism is developed in the metasedimentary rocks around the HP. The hornfels is manifested primarily by porphyroblasts of inclusion-rich cordierite and andalusite (chiastolitic variety) and a general silicification of the rock. Porphyroblasts are generally unoriented, but in a few locations orientation of the minerals in the plane of foliation may indicate syntectonic growth. Porphyroblasts may, therefore, have been growing prior to the actual emplacement of the granites at the present leve1, with the heat source being the underlying (rising) granites (O'Brien, personal communication, 1987).

For the most part the emplacement of the SMB has not disturbed the regional structural trends within the Meguma Group, thus prompting Smith (1974) and McKenzie and Clarke (1975) to assume a passive stoping emplacement mechanism. However, Faribault (1908) has mapped the "Transverse Anticline" and "Transverse Syncline" in the Hammond's Plains area on the northern flank of the HP. As the name implies, these structures are perpendicular to the regional trend and occur proximal to the granite contact. Similar structures were noted in the Mahone Bay area by 0'Brien (personal communication, 1987) where the regional structures appear to be oriented parallel to the granite/metasedimentary rock contact. Thus, while most evidence indicates a passive stoping mechanism of emplacement for the SMB, locally forceful intrusion may have occurred.

\section{Endocontact}

The most spectacular example of contact-related phenomena is exposed at Chebucto Head (Fig. 2) in the Harrietsfield monzogranite (unit 4). Features including finely laminated (schlieren-like) bands with cross-cutting (cross-bedding?) relationships and dykes of alkali feldspar megacrysts and xenoliths have been interpreted by Smith (1975) to represent flow sorting and episodic shearing during the emplacement of the SMB. Clarke and Muecke
(1980) related the same layering to episodic flowage of magma through narrow orifices which filtered out coarse material. Some of these features have been observed elsewhere in the HP; however, nowhere are they as spectacular as at Chebucto Head. Regardless of which interpretation is chosen, the layering at Chebucto Head presumably reflects the emplacement of a crystal mush which behaved essentially as a fluid.

Other than the above features, there are relatively few endocontact effects in the HP. The granitic rocks are not chilled and there is no significant increase in the abundance of xenoliths next to the metasedimentary rocks.

\section{Xenoliths}

Xenoliths in the HP can be classed as: (1) "fresh" Meguma-like xenoliths typically with primary sedimentary features $+/$ - porphyroblasts of andalusite and cordierite; (2) fine-grained equigranular xenoliths commonly exhibiting "gneissic" (?) banding; (3) fine- to medium-grained xenoliths with abundant medium- to coarse-grained megacrysts of quartz, alkali feldspar and plagioclase; and (4) medium- to coarse-grained xenoliths with a "ghostlike" appearance (i.e., granitic rocks with a slightly higher biotite content). Of the above groups, only 非 i is conclusively of "Meguma" origin.

Units characterized by the highest xenolith content are those with the highest biotite content, e.g. , granodiorite (unit 1) and Sandy Lake/Peggy's Cove monzogranites (units $2 a$ and $2 b$ ); all of the above xenolith types can be observed in these units. The more evolved, biotite-poor rocks have fewer xenoliths (mostly types 2-4) even when in direct contact with the Meguma metasedimentary rocks (e.g., unit 6 at Ferguson's Cove).

\section{Distribution of Units and Contact Relationships}

Figure 2 shows the results of recent detailed geological mapping in the HP. Rocks of the HP can be divided into two sequences on the basis of texture and field relationships. These are: (A) a zoned sequence of biotite granodiorite (unit 1), biotite monzogranite (units $2 a$ and $2 b$ ), muscovitebiotite +/-cordierite leucomonzogranite (unit 3 ), cordierite-biotite monzogranite (unit 4a), biotite monzogranite (unit 4); and (B) muscovite-biotite leucomonzogranite (units $5 a, 5 b, 5 c$, and 6 ). Previous mapping by Smith (1974) indicated the presence of two separate sequences, and suggested that the HP was zoned; however, the rocks were not as rigorously subdivided as in the present study. In addition, Smith (1974) classified the sequence B rocks as alaskites whereas they commonly contain substantial biotite $+/$-cordierite $(>5 \%)$ which is similar to some sequence A rocks (e.g., unit 3 ).

Sequence A rocks are mostly light grey, fine- to coarse-grained, and megacrystic with varying proportions of alkali feldspar, plagioclase, biotite and cordierite. Appreciable amounts muscovite (i.e., >1\%) are found only in unit 3 .

Sequence B rocks, of variable colour and texture, are predominantly porphyritic and equigranular, fine- and medium- grained, predominantly muscoviteand biotite-bearing, and commonly contain andalusite. 


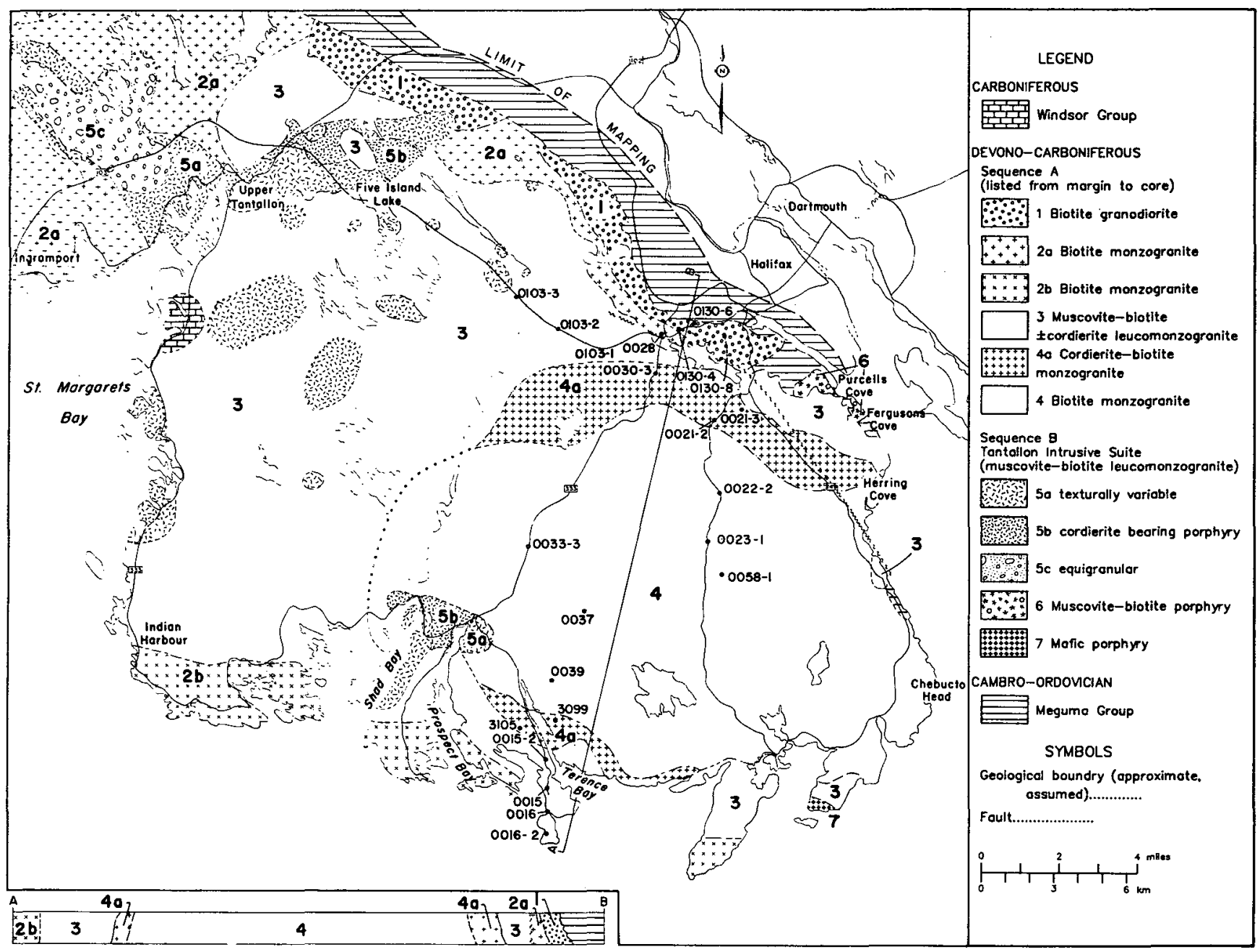

F1g. 2. Geological map of the Halifax Pluton, NTS map sheets 11D/05 and 11D/12.

Contacts between the units in the zoned sequence (A) are rare1y exposed, but where observed are predominantly gradational but locally sharp (Intrusive). We11 exposed gradational contacts were observed between units 1 and $2 a, 2 b$ and 3 , and 4 and $4 a$. However, an intrusive contact between units $2 b(?)$ and 3 is exposed near Indian Harbour. An intrusive contact between units 3 and 4 is exposed along the shoreline north of Chebucto Head; no contact features are present (e.g.. chilling, xenoliths or dykes), and thus relative age relationships could not be determined. Elsewhere the transition between units 3 and 4 is gradational with unit 3 becoming enriched in biotite and 4 a becoming coarser with more alkall feldspar megacrysts with increased proximity to the contact. Simllar gradational to sharp intrusive contacts have been observed elsewhere in the SMB and presumably reflect movement of co-magmatic rocks during crystallization.

The boundary between sequences $A$ and $B$ is invariably marked by sharp intrusive contacts (e.g., near Five Island Lake, north of Ingramport and west of Purcel1's Cove) with some xenoliths of sequence A occurring in sequence $B$ (e.g., northwest of Upper Tantallon along Highway 非103), Implying that sequence $B$ represents a later intrusive event.
The contact between units $5 a$ and $5 c$, although poorly exposed, is inferred to be gradational with unit 5a possibly representing a chilled margin to $5 c$. The contact between unit $5 b$ and the rest of the Tantalion Intrusive Sulte (TIS) is not exposed, but is inferred to be intrusive. The biotite-rich nature of unit $5 \mathrm{~b}$ suggests that $1 \mathrm{t}$ is the most "primitive" member of TIS.

\section{PETROLOGY}

A detalled petrographic study of more than 250 representative thin sections from the HP was conducted and is summarized in Table 1 . The zonality of the HP 1s expressed by subtle petrographic variations which include:

(1) The abundance of alkall feldspar megacrysts. Traversing inward from the margin of the HP alkali feldspar megacrysts increase from $<2 \%$ in unit 1 to $10-15 \%$ in unit $2 a$ (and $2 b$ ) and $15->50 \%$ in unit 3 . A decrease in the amount of megacrysts is noted near the core of the pluton (1.e., 10-15\% in unit 4).

(2) The type of zoning displayed by individual plagloclase crystals varies, with spectacular examples of oscillatory and normal zoning occurring within units 1 and 2, and predominant1y normal1y 
Table 1. Petrographic Features of the Halifax Pluton.

\begin{tabular}{|c|c|c|c|c|c|c|c|c|c|c|c|c|c|c|c|c|c|c|c|c|c|c|c|c|}
\hline onsts & Rocx & \begin{tabular}{|c|}
$\operatorname{conaxm}$ \\
$\sin$
\end{tabular} & TExTURE & nEaA- & PnDaso- & PLACIOCLAS & 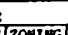 & & & 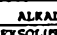 & pros & & & oriTR & Ruscovite & $T$ & Int & conos & IERTTE & $\pi$ & GARp & SET & त्T & \begin{tabular}{|l} 
ANDALUSITE \\
OI
\end{tabular} \\
\hline & & & & & & Compositio & 20NINGC & Mrensaitie & NLT & Exsoum & & & (i) & & $(0)$ & ]REPL & DIK & & FRESH & NTr & (11) & & cLust & \\
\hline 1 & CD10 & $\begin{array}{ll}2 \rightarrow \infty \\
\operatorname{anr} c\end{array}$ & NDEA & $0-1$ & & $A n$ is-33 & 23113 & cosemon & $0-1$ & 1 & & 1 & $12-15$ & $0-1$ & erece & $\mathrm{XP}$ & & $\begin{array}{l}0- \\
\text { irace }\end{array}$ & none & PI & & & & \\
\hline $\begin{array}{l}28 \\
80 \\
20\end{array}$ & (copio) & $-a$ & MBGA & $1>2$ & & An $11-36$ & $\begin{array}{l}231133 \\
7>0\end{array}$ & common & $0-1$ & 1172 & ereces & 1 & $10 \sim>12$ & $0-1$ & $\begin{array}{l}\text { erace } \\
-\ll 1\end{array}$ & $x F>>C$ & \begin{tabular}{|l|} 
erace \\
\end{tabular} & $0-1$ & \begin{tabular}{|l|} 
erace \\
\end{tabular} & 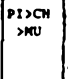 & 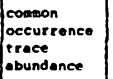 & $\times$ & & \\
\hline 4 & nowz & $\varepsilon-\mathrm{c}$ & (stan $)$ & 1 & & an $3-30$ & $\mid \begin{array}{l}1,2223 \\
>>0\end{array}$ & comonon & $\mid \begin{array}{ll}0-1 \\
2>2-3\end{array}$ & $\begin{array}{l}1>2 \\
>>0\end{array}$ & & $1-2$ & $8-10$ & $1(2)$ & 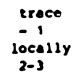 & 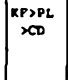 & |erace & 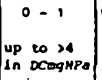 & erace & $\begin{array}{c}p 12(n) \\
m 0\end{array}$ & $\left|\begin{array}{l}\text { Lreace } \\
\text { oceur rence } \\
\text { ond } \\
\text { obundoance }\end{array}\right|$ & & $x$ & \\
\hline 3 & $\begin{array}{l}\text { MON2 } \\
\text { (SYEN) }\end{array}$ & $e-\mathrm{c}$ & MEeAn & $1-2$ & & An2-27 & $1>0>2$ & treces & $2-3$ & 100 & trace & 2 & $22->6$ & $1-4$ & $\begin{array}{l}1-2 \\
10 \cos 11 y \\
3-1\end{array}$ & $\begin{array}{c}\mathrm{XP}>(D) \\
\mathrm{PL}\end{array}$ & comanon & $\begin{array}{rr}0-14 \\
\text { avg } 1-2\end{array}$ & none & $\mid \begin{array}{l}\text { wropch } \\
>P P I\end{array}$ & \begin{tabular}{|l|} 
eracec \\
occurrencec \\
- arundence
\end{tabular} & & $x$ & \\
\hline Sac & $\begin{array}{l}\text { ISYNa) } \\
\text { (SYBa) }\end{array}$ & $2, \ldots, c$ & 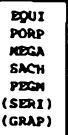 & $0>1$ & 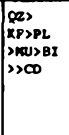 & $A n_{1-15}$ & $0>1$ & none & $2-3$ & $0 \times 1$ & comon & -3 & $11-4$ & 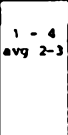 & $1-24$ & $\mid \begin{array}{l}x p>C D \\
>B I\end{array}$ & conconon & \begin{tabular}{|c|} 
common \\
occur rences \\
ersoce \\
obundence
\end{tabular} & none & $\mid \begin{array}{ll}\mathrm{NurCH} \\
\geqslant P \mathrm{PI}\end{array}$ & & & & $\begin{array}{l}\text { common } \\
\text { occurrence } \\
\text { erace- } \\
\text { 2ocally 2 }\end{array}$ \\
\hline SD & nON2 & e-c & DORP & T & \begin{tabular}{|l|}
$X P P P Q P$ \\
$P P Q>\infty$
\end{tabular} & $\begin{array}{l}\ln _{16-28^{\circ}} \\
\operatorname{An}_{2-4}\end{array}$ & $1230^{\circ}$ & none & $\begin{array}{l}2-3 \\
1-2\end{array}$ & 120 & an nor & 2 & $4-15$ & $3-9$ & $2-3$ & $\mid \begin{array}{c}x p>p P \\
p>\infty\end{array}$ & erace & (1-2 & none & \begin{tabular}{|l|} 
MUPPI \\
\end{tabular} & & & & \\
\hline B & nON2 & \begin{tabular}{|l|}
$p-a$ \\
$a-c$
\end{tabular} & $\begin{array}{c}\text { PORP } \\
\text { (GRAP) }\end{array}$ & $T$ & $\begin{array}{l}p_{2>\rho 2} \\
>X P>P B I\end{array}$ & 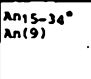 & ox1 & none & \begin{tabular}{|l|}
$a-4$ \\
ovg 2
\end{tabular} & $0>1$ & none & 2 & $21-5$ & $1-3$ & $22-110$ & $K F>\infty$ & comenon & $0-1$ & none & 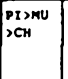 & & & & 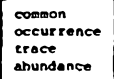 \\
\hline 7 & nonz & \begin{tabular}{l|}
-1 \\
$-c$
\end{tabular} & PORP & 0 & $\begin{array}{c}p<p(2) \\
k P P\end{array}$ & An 15-30 & 2210" & conson & $0-2$ & $T$ & none & \begin{tabular}{|l|}
1 \\
\end{tabular} & $12-15$ & $0-1$ & trace - & 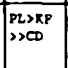 & ereces & 0 - trace & \begin{tabular}{|l|} 
none \\
\end{tabular} & pismu & \begin{tabular}{|l|}
$\begin{array}{l}\text { Eracee } \\
\text { occurrence } \\
\text { - obundence }\end{array}$ \\
\end{tabular} & & $x$ & \\
\hline
\end{tabular}

ExpLasutzos

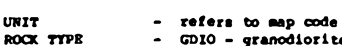

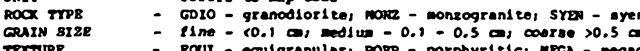

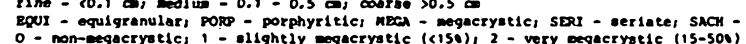

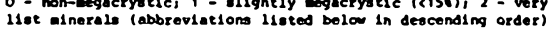

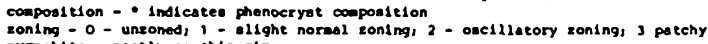

cylmokite - mostiy as ciln rias

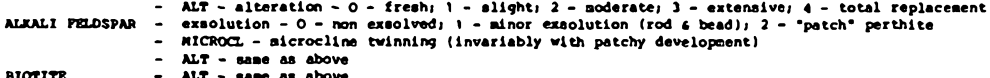

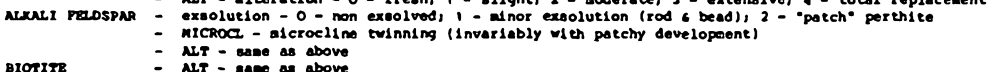

BIOTIY8

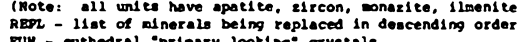

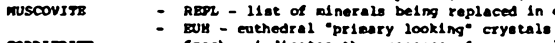

CORDIERITE : Irooh - Indicates ene presence of cose unaltered actertal

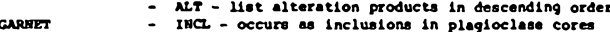

Cluat - associated with blotite clustere (xenocrysetcr)

LIST OP MANERAL NBBREVIATYONS

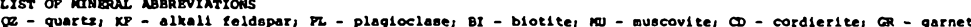

NOTES:

1. All quarte dloplays undulose extinction and coamonly developaent of eubgraln

zoned or unzoned crystals in unit 3. In the core, unit 4 plagloclase displays normal and oscillatory zoning similar to that in the outer HP.

(3) Myrmekitic rims on plagloclase are most abundant in units $1,2 a, 2 b$, and in the core of the pluton (unit 4), whereas this feature is absent from most samples of unit 3 .

(4) The presence and type of perthitic exsolution in alkall feldspar varies from margin to core of the HP. Perthitic features in units $1,2 a$, and $2 b$ are predominant1y "rod" and "bead" type where the exsolved albite constitutes approximately $10-15 \%$ of the crystals. In contrast, alkali feldspar in unit 3 has abundant "patch perthite" where albite may constitute up to $50 \%$ of individual crystals. In the core of the HP, unit 4 contains rod and bead exsolution; however, patch perthite may be present in minor amounts.

(5) Blotite varies in modal abundance from $12-15 \%$ in unit 1 , to $10-12 \%$ in units $2 a$ and $2 b, 2-7 \%$ in unit 3 and $8-10 \%$ in unit 4 . Blotite compositions (unpublished microprobe data) also vary from most "primitive" (1.e., lowest $\mathrm{Fe} /(\mathrm{Fe}+\mathrm{Mg})$ in units 1 $(0.637), 2 a(0.642)$, and $2 b(0.649)$, to the more evolved compositions in unit $3(0.750)$ and then more "primitive" in unit $4(0.641)$.

(6) Muscovite increases from the margin of the $\mathrm{HP}$ (1.e., trace to $<1 \%$ in units $1,2 a$, and $2 b$ ) to $1-4 \%$

In unit 3 and then decreases slightly to trace to $1 \%$ (locally 2-3\%) in unit 4. Euhedral, primarylooking crystals are essentially absent in units 1 , $2 a, 2 b$, and 4 , whereas they are present in unit 3 .

(7) Cordierite is present in trace to minor amounts in most rocks, however, at the boundary between units 3 and 4 cordierite may constitute up to $>5 \%$ of the mode. There is generally a progressive change in alteration of cordierite from predominantly pinite (with minor chlorite and muscovite) in the more "primitive" rocks (1.e., units $1,2 a, 2 b$, and 4) to predominant1y muscovite and chlorite with minor pinite in unit 3 . This may reflect interaction of the cordierite phase with a progressively evolving flutd phase.

(8) The degree of alteration increases from unit 1 to $2 a$ and $2 b$, and then to unit 3 , followed by $a$ decrease in unit 4 . In addition to the alteration of cordlerite described above, alteration features include: (1) sericitization of plagloclase (especially in the more calcic cores); (11) sericitization of alkall feldspar; (111) chloritization of blotite; and (iv) the replacement of plagloclase by alkall feldspar.

As previous $1 \mathrm{y}$ mentioned, field relations indicate that sequence $B$ rocks represent a separate, relatively younger intrusive event(s). A detailed investigation of these rocks indicates that there 
are substantial petrographic differences from the "older" zoned sequence. These features are summarized as follows:

(1) Colour is often buff, grey, orange, pink and red (cf. whitish-grey sequence A rocks).

(2) Grain sizes are generally fine- to mediumgrained with very little coarse grained material, except for local pegmatites and minor coarsegrained phenocrysts (cf. coarse-grained megacrystic phases in sequence A rocks).

(3) Texture is predominantly porphyritic and equigranular with minor megacrystic, saccharoidal, pegmatitic, graphic and serlate textures (cf. megacrystic texture in sequence A rocks).

(4) Plagioclase is generally unzoned and of albitic composition (compositions determined both optically and by microprobe analysis), except for plagloclase phenocrysts (of oligoclase-albite composition with some andesine) (cf. zoned plagioclase of andesine to albite composition in sequence $A$ ).

(5) Myrmekitic rims, a common feature in the more mafic rocks of the zoned sequence $(A)$, are absent in sequence $B$.

(6) Biotite (0-5\%) is generally less abundant than in the majority of the rocks of sequence A (4 to $>15 \%$ ). Compositions are for the most part more evolved with higher $(\mathrm{Fe} / \mathrm{Fe}+\mathrm{Mg})$ ratios $(\mathrm{e} . \mathrm{g} ., 0.868$ for units $5 a$ and $c$ ).

(7) Muscovite is more abundant (1-10\%) than in the majority of sequence $A$ rocks except for local areas of unit 3 where up to $4 \%$ muscovite occurs. Primary-10oking, euhedra1 muscovite grains are common in sequence $B$ whereas they are uncommon in sequence A (except in some samples of unit 3 ).

(8) Alteration products after cordierite are predominantly muscovite and chlorite (i.e., similar to unit 3) as opposed to pinite in the biotite-rich rocks of sequence $A$.

(9) Andalusite is a common accessory in sequence $B$ rocks (1.e., observed in $50 \%$ of samples) compared to its rare occurrence in sequence A 1ithologies.

In summary, there are subtle yet consistent petrographic differences between the units which define the zoned sequence $(A)$ as outlined in Table 1. These petrographic features suggest that the marginal areas of the HP are normally zoned. Conversely, the core of the pluton (1.e., units 4 and 4a) is slightly less evolved than the surrounding rocks of unit 3 , thus a reverse zonation is represented.

A clear distinction can also be made petrographically between the rocks of sequence $A$ and sequence $B$ which supports the hypothesis of separate crystallization histories for the two suites.

\section{GEOCHEMISTRY}

Considerable geochemical data have been published for the granitic rocks of the HP; however, several problems are involved in integrating this data into the present survey. The data presented in Smith (1974) could not be used because sample locations were not provided and the rock units do not correspond to the units presented in this study. For example, "granodiorite" in Smith (1974) includes units $1,2 a$, and $2 b$ whereas "quartz monzonite" includes rocks from units $2 b, 3,4$, and $4 \mathrm{a}$ of this study. Sample locations were provided in a more recent re-appraisal of the $\mathrm{HP}$ (Smith et al., 1986); however, investigations of most of these locations indicated that glacially transported boulders were often sampled. These boulders commonly represented a different unit than the underlying bedrock and, therefore, several of the interpretations presented in Smith et al. (1986) are suspect. Thus, a comprehensive geochemical study was undertaken to: (1) establish the geochemical composition of the each rock unit; (2) quantify the nature and degree of geochemical zoning in sequence A rocks; and (3) establish the compositional ranges for sequences $A$ and $B$ and thus determine the relationship between the two suites.

One hundred and sixteen representative samples were chosen for major and trace element chemical analysis. Sample selection was based on results of systematic geological mapping, investigation of stained slabs and detailed petrography of more than 250 thin sections. A minimum of $25 \mathrm{~kg}$ of material was collected from large outcrop areas to eliminate potential problems of heterogeneity. Samples were crushed to less than $2.5 \mathrm{~cm}$ and homogenized, and then approximately $4 \mathrm{~kg}$ of fresh material was handplcked to eliminate weathering, fracturerelated alteration and xenoliths. This material was ultrasonically cleaned, dried, crushed to less than $5 \mathrm{~mm}$ and split to form a $200 \mathrm{gm}$ subsample which was subsequently crushed in a shatter box to minus 200 mesh.

Bench standards were prepared for quality control in the analytical procedures. Standard 非 is a medium grained, non-megacrystic biotite granodiorite which was collected in a rock quarry near Nictaux (Fig. 1). Standard \#2 is a biotite monzogranite which was collected along Highway 非103 near the Aspotogan Peninsula (Fig. 1). Approximately $200 \mathrm{~kg}$ of fresh material was collected and crushed according to the above procedure. Mean values and standard deviations for trace and major element compositions for the two standards are presented in Table 2.

Samples, analytical splits and bench standards were sent to the Nova Scotia Regional XRF Centre at St. Mary's University for analysis of major elements and a suite of trace elements ( $\mathrm{Ba}, \mathrm{Rb}, \mathrm{Sr}$, $\mathrm{Y}, \mathrm{Zr}, \mathrm{Nb}, \mathrm{Pb}, \mathrm{Zn}, \mathrm{Cu}, \mathrm{N} 1, \mathrm{~V}$ and $\mathrm{Cr}$ ). The same suite of samples and standards was sent to BondarClegg Laboratories for analysis of $\mathrm{Sc}, \mathrm{As}, \mathrm{Rb}, \mathrm{Sb}$, $\mathrm{Ba}, \mathrm{La}, \mathrm{Hf}, \mathrm{Ta}, \mathrm{W}, \mathrm{Au}, \mathrm{Th}, \mathrm{U}, \mathrm{Li}, \mathrm{B}, \mathrm{F}$ and $\mathrm{Sn}$.

A summary of all geochemical results and normative mineralogy is presented in Table 2. Means and standard deviations are presented for groups with more than nine samples, whereas only the means are given for smaller subsets. Table 2 also contains averaged data and C.I.P.W. normative values for granodiorite, monzogranite, dike rocks and minor intrusions from the central part of the SMB (McKenzie and Clarke, 1975).

\section{Major Elements}

The outer portion of the zoned sequence (A) from unit 1 to unit 3 is marked by a progressive increase in $\mathrm{SiO}_{2}(68.11-72.95 \%)$ and a concomitant decrease in $\mathrm{Ti}_{2}(0.59-0.20 \%), \quad \mathrm{Al}_{2} \mathrm{O}_{3}(15.52-$ $14.32 \%), \quad \mathrm{Fe}_{2} \mathrm{O}_{3}{ }^{2}(4.18-2.09 \%)$, MnO (0.09-0.05\%), $\mathrm{MgO}(1.50-0.37 \%) \mathrm{t}$ and $\mathrm{CaO}(1.79-0.64 \%)$. Normative quartz, orthoclase, corundum and Thornton-Tuttle Differentiation Index (TTDI) increase toward unit 3 whereas normative anorthite, enstatite, 
Table 2. Average major and trace element chemistry and normative mineralogy for various units of the Halifax Pluton. Table also contains averaged compositions for granodiorite, adamellite (i.e., monzogranite) and dike rocks and minor intrusions from the central SMB (after McKenzie and Clarke, 1975), and results for the two bench standards used in this study.

\begin{tabular}{|c|c|c|c|c|c|c|c|c|c|c|c|c|c|c|c|c|c|}
\hline & \multicolumn{6}{|c|}{, } & & & \multicolumn{5}{|c|}{ Rerenenzite sad Clarke (1975) } & \multicolumn{2}{|c|}{ semanatas } \\
\hline unstr & 1 & 20 & $2 \mathrm{~b}$ & & 4 & 3 & s.c. & 30 & 6 & 7 & Grendiorite & Henzessyatis & & Drke pock & & 500. & $500 \% 2$ \\
\hline 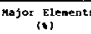 & $\bar{x}=10^{50}$ & $\overline{\bar{x}}, g^{s 0}$ & $\frac{\vec{x}}{x=10}$ & & 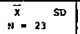 & $\begin{array}{ll}\bar{x} \\
N=25\end{array}$ & $\begin{array}{l}\bar{x} \\
x-17^{50}\end{array}$ & $\frac{\bar{x}}{n-}$ & $\begin{array}{ll}\bar{x} \\
n-5\end{array}$ & $\frac{\bar{x}}{n+-2}$ & $\begin{array}{|lc|}\bar{x} & 50 \\
x-10 & 50\end{array}$ & \begin{tabular}{|l|l|}
$\bar{x}$ \\
$x-10$
\end{tabular} & so & $\frac{\bar{x}}{n=10}$ & so & $\bar{x}=10$ & $\begin{array}{ll}\bar{x} \\
15-12\end{array}$ \\
\hline$\overline{\mathrm{sio}_{2}}$ & $\begin{array}{llll}68.11 & 0.71\end{array}$ & 689.301 .110 & 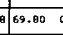 & 0.417 & 17.33 1.39. & 12.950 .80 & 0.69 & $n .69$ & 74.5 .5 & 9.01 & $\begin{array}{ll}.13 & 1.32 \\
\end{array}$ & $33.42 \quad 1$. & 1.27 & $78.38 \quad 1$. & & $68.01 \quad 0.05$ & $70.68-0.66$ \\
\hline $\mathrm{TiO}_{2}$ & $0.59 \quad 0.02$ & 0.480 .10 & 0.000 & \begin{tabular}{l|l}
0.05 & 0 \\
\end{tabular} & 0.400 .09 & 0.200 .07 & $0.09 \quad 0.04$ & 0.21 & 0.18 & 0.42 & \begin{tabular}{ll|}
0.62 & 0.10 \\
\end{tabular} & $0.24 \quad 0$. & 0.09 & $\begin{array}{ll}0.15 & 0 .\end{array}$ & 0.02 & $\begin{array}{lll}0.37 & 0.00 \\
\end{array}$ & $0.37 \quad 0.01$ \\
\hline & 13.520 .0 .19 & 19.110 .15 & 915.100 & $0.43 \times 1.430$ & 14.49 0.41 & 0.33 & 0.34 & 10.91 & 13.99 & & $.37 \quad 0.33$ & 13.740. & 0.40 & 13.90. & & $16,470.18$ & \begin{tabular}{|lll}
14.56 & 0.23 \\
\end{tabular} \\
\hline$=2031$ ( & \begin{tabular}{|ll|l|} 
& 0.16 & 0.19 \\
\end{tabular} & 3.590 .66 & $63.06=$ & 0.29 & $2.99 \quad 0.47$ & 2.090 .36 & $1.34 \quad 0.20$ & 2. & 1.99 & 3.24 & $\begin{array}{ll}.49 & 0.57 \\
\end{array}$ & $2.04 \quad 0$ & 0.30 & $\begin{array}{lll}7.47 & 0 . \\
\end{array}$ & 0.39 & $\begin{array}{lll}3.36 & 0.02 \\
\end{array}$ & $3.28 \quad 0.08$ \\
\hline$m \times 0$ & 0.090 .01 & $\mid 0.080 .01$ & 0.070 & 0.005 & $0.06 \quad 0.01$ & \begin{tabular}{|c|c|}
0.05 & 0.01 \\
\end{tabular} & $0.05 \quad 0.01$ & 0.05 & 0.05 & 0.0 & $\begin{array}{lll}0.10 & 0.01\end{array}$ & 0.110 & 0.15 & $0.04 \quad 0$. & 0.01 & $\begin{array}{llll}0.07 & 0.00 \\
\end{array}$ & $\begin{array}{lll}0.08 & 0.00\end{array}$ \\
\hline $\mathrm{ngO}^{\circ}$ & $1.50 \quad 0.06$ & \begin{tabular}{|l|l|l|l|}
1.33 & 0.16 \\
\end{tabular} & 6 & 0.11 & $1.04 \quad 0.09$ & 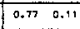 & 6.0 .1 & 1.0 & & & $\begin{array}{ll}1.05 & 0.20 \\
\end{array}$ & $0.15 \quad 0$. & 0.12 & $0.19 \quad 0$. & 0.13 & $\begin{array}{lll}.46 & 0.04 \\
\end{array}$ & 110.04 \\
\hline $\cos$ & 1.790 .11 & 1.000 .32 & \begin{tabular}{|l|l|l|l|}
12.30 & 0 \\
\end{tabular} & 0.12 & 1.070 .24 & \begin{tabular}{|l|l|l|}
0.64 & 0.19 \\
\end{tabular} & $\begin{array}{lll}0.36 & 0.06 \\
\end{array}$ & 5 & 0.45 & 4.8 & \begin{tabular}{ll|}
.99 & 0.23 \\
\end{tabular} & $0.67 \quad 0$. & 0.19 & $0.52 \quad 0$. & 0.15 & & 1.180 .01 \\
\hline $\mathrm{x} x z_{z}$ & 1.490 .05 & $3.35 \quad 0.12$ & 3.220 & 0.15 & $\begin{array}{llll}3.22 & 0.13 \\
\end{array}$ & \begin{tabular}{|l|l|l|}
3.22 & 0.15 \\
\end{tabular} & \begin{tabular}{|lll}
5.45 & 0.39 \\
\end{tabular} & 3. & & & \begin{tabular}{ll|}
3.29 & 9.19 \\
\end{tabular} & 3.36 & .12 & 3.58 & 0.4 & $\begin{array}{ll}0.18 & 0.16 \\
\end{array}$ & 990.50 \\
\hline $\mathrm{\kappa}_{2}{ }^{\circ}$ & \begin{tabular}{|l|l|}
13.80 & 0.11 \\
\end{tabular} & 4.290 .13 & $\sqrt{14.00}$ & 0.34 & \begin{tabular}{ll|}
4.40 & 0.16
\end{tabular} & \begin{tabular}{|l|l|}
4.56 & 0.110 \\
\end{tabular} & $\begin{array}{lll}4.42 & 0.21\end{array}$ & 4.19 & 4.4 & 3.8 & \begin{tabular}{cc|}
1.84 & 0.28 \\
\end{tabular} & 0.750 & 0.24 & $\begin{array}{lll}4.53 & 0 .\end{array}$ & 0.45 & $\begin{array}{lll}1.98 & 0.07\end{array}$ & $\begin{array}{lll}.34 & 0.05\end{array}$ \\
\hline & \begin{tabular}{|l|l|}
0.19 & 0.01 \\
\end{tabular} & \begin{tabular}{|ll}
0.19 & 0.01 \\
\end{tabular} & $\begin{array}{lll}10.15 \\
\end{array}$ & 0.02 & $\begin{array}{lll}0.25 & 0.02\end{array}$ & \begin{tabular}{|l|l|}
0.27 & 0. \\
\end{tabular} & \begin{tabular}{|lll}
0.25 & 0.07
\end{tabular} & 0.3 & & & $\begin{array}{ll}0.09 & 0.03\end{array}$ & 0.12 & 0.08 & 0.16 & 0.10 & $0.140 . \infty$ & 0.00 \\
\hline L.0.2. & 50.12 & \begin{tabular}{|l|l|}
0.62 & 0.11
\end{tabular} & 3 & 0.13 & $\begin{array}{lll}0 . & 0 . & 0 .\end{array}$ & 0.530 & 0.68 & & & & .98 & 0.76 & 0.15 & 0.78 & 0.10 & $0.67 \quad 0.12$ & $\because 0$ \\
\hline Fork & & & & & & & & & & & .39 & 33 & & 9.42 & & & \\
\hline
\end{tabular}

cis.

\begin{tabular}{|c|c|c|c|c|c|c|c|c|c|c|c|c|c|c|}
\hline $\mathrm{q}$ & 27.94 & 29.21 & 29.26 & 32,89 & 34.79 & 36.56 & 32.71 & 37.87 & 23.14 & 30.13 & 34.50 & 35.73 & 28.56 & 31.55 \\
\hline OR & 22.62 & 25.57 & 28.11 & 26.21 & 27.77 & 26.24 & 26.99 & 26.50 & $27,46$. & 22.94 & 29.4 & 27.11 & 11,03 & 25.91 \\
\hline$A B$ & 29.75 & 28.59 & 27.51 & 27.46 & 27.48 & 29.48 & 30.06 & 26,50 & 34.93 & 28.06 & 28.78 & 90.68 & 35,67 & 25.56 \\
\hline$A B$ & 7.70 & 5.75 & 5.46 & 3.70 & 1.75 & 0.10 & 2.44 & 0.86 & 3.41 & 9.34 & 2.57 & 1.55 & 13.67 & 4.73 \\
\hline${ }^{c}$ & 2.99 & 2.89 & 2.76 & 3.11 & 3.37 & 3.74 & 3.73 & 3.66 & 8.16 & 1.45 & 2.17 & 2.39 & 2.61 & 3.26 \\
\hline$E N$ & 3.76 & 3.34 & 2.94 & 2.61 & 8.93 & 1.48 & 2.59 & 1.4.2 & 7.11 & 2.64 & 0.88 & 0.48 & 3.58 & 2.79 \\
\hline $\mathrm{IL}$ & 0.17 & 0.17 & 0.15 & 0.13 & 0.13 & 0.11 & 0.11 & 0.13 & 0.15 & 0.22 & 0.26 & 0.09 & 0.15 & 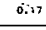 \\
\hline${ }^{\mathrm{sm}}$ & 4.21 & 3.62 & 3.10 & 2.96 & 2.11 & 1.35 & 2.48 & 1.95 & 3.23 & 4.49 & 2.05 & 1.48 & 3.10 & 3.31 \\
\hline "Kr & 3.76 & 3.34 & 2.94 & 2.61 & 1.93 & 1.48 & 2.59 & 1.4. & 7.11 & 2.59 & 0.88 & 0.40 & 9.66 & 2.79 \\
\hline RU & 0.19 & 0.39 & 0.32 & 0.34 & 0.13 & 0.02 & 0.25 & 0.11 & 0.34 & 0.51 & 0.12 & 0.11 & 0.30 & 0.28 \\
\hline $\mathbf{A P}^{\mathrm{P}}$ & 0.15 & 0.45 & 0.38 & 0.60 & 0.53 & 0.50 & 0.52 & 0.50 & 0.47 & 0.22 & 0.29 & 0.38 & 0.34 & 0.43 \\
\hline TTDI & 83.21 & 86.26 & 87.64 & 89.66 & 93.42 & 96.34 & 97.50 & 94.63 & 81.29 & 82.59 & 93.83 & 95.91 & 78.57 & 89.28 \\
\hline
\end{tabular}

\begin{tabular}{|c|c|c|c|c|c|c|c|c|c|c|c|c|c|c|c|c|c|c|c|c|c|c|c|c|c|}
\hline UIIIT & 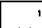 & 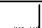 & & $a$ & & $2 \mathrm{z}$ & & 4 & & 2 & & $\overline{s . c}$ & $s b$ & 6 & $?$ & & iri te & & nitto & & ocks & STD & & ST0 & \\
\hline 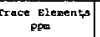 & $\overline{\bar{x}}$ & so & $\overline{\bar{x}}$ & st & $\overline{\bar{x}}$ & SD & $\overline{\bar{x}}$ & $\mathrm{SE}$ & $\overline{\bar{x}}$ & so & $\overline{\bar{x}}$ & so & $\overline{\bar{z}}$ & $\bar{x}$ & & $\overline{\mathrm{x}}$ & so & $\bar{x}$ & sD & $\overline{\bar{x}}$ & SD & $\overline{\bar{x}}$ & so & $\overline{\bar{x}}$ & 50 \\
\hline$B$ & 589 & 84 & 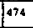 & 149 & 442 & 123 & 355 & to3 & 208 & 92 & 59 & 85 & 258 & 137 & 354 & 691 & 79 & 253 & 134 & 131 & 155 & 369 & 9 & 440 & 7 \\
\hline $\mathrm{Bb}$ & 164 & 17 & 203 & 70 & 194 & 12 & 238 & 27 & 275 & 42 & 349 & 10.1 & 256 & 286 & 201 & 145 & 17 & 334 & ${ }_{92}$ & 451 & 208 & 65 & 1 & 219 & 6 \\
\hline sr & 17 & 22 & 122 & 35 & 116 & 26 & \begin{tabular}{|l|}
94 \\
\end{tabular} & 27 & 57 & 27 & 10 & 13 & $\pi$ & 34 & 120 & 191 & 25 & $" 1$ & 18 & 70 & 18 & 314 & 2 & 108 & 1 \\
\hline HF & 6 & 0.5 & 4 & 1.3 & 4 & 0.3 & 4 & 1.0 & 3 & 8.0 & 1 & 0.5 & 3 & 2 & 3 & & & & & & & 3 & 0.3 & 4 & 0.4 \\
\hline$z x$ & $m$ & 14 & 148 & 26 & 128 & 19 & 132 & 19 & \begin{tabular}{|l|}
86 \\
\end{tabular} & 23 & 45 & 13 & 103 & \begin{tabular}{|l|}
73 \\
\end{tabular} & 119 & 210 & 44 & 8s & 35 & 34 & 43 & 106 & 2 & 140 & 3 \\
\hline to & 1.1 & & 1.8 & 1.0 & 1. & 0.1 & 1. & 0,3 & & 0.5 & 2.6 & 1.1 & 2.0 & 1.9 & 1.3 & & & & & & & 0.9 & 0.2 & 1.1 & 0.2 \\
\hline wh & \begin{tabular}{|l|}
12 \\
\end{tabular} & 0.9 & 12 & 1.0 & 10 & 0.6 & 14 & 1.5 & 11 & 1.4 & 31 & 3.0 & 13 & $" 1$. & 11 & & & & & & & 16 & 1 & $"$ & 0.5 \\
\hline Se & 9.4 & 1.2 & 7.1 & 18 & 6. & 1.2 & 5.8 & 91.1 & & 0.8 & 2.8 & 0.8 & 4.7 & 3.7 & 7.1 & & & & & & & 5.3 & 0.2 & 5.9 & 0.3 \\
\hline $\mathrm{v}$ & 44 & 5 & 31 & 9 & 25 & 6 & 28 & 8 & 12 & 6 & 3 & 2 & 20 & 8 & 35 & & & & & & & 28 & 2 & 27 & 3 \\
\hline La & 34 & $\mathrm{~J}$ & 28 & 2 & 25 & 5 & 24 & 4 & 15 & 5 & 5 & 3 & 17 & 12 & 21 & & & & & & & 18 & 1 & 26 & 2 \\
\hline$y$ & 32 & 3 & 31 & 2 & 29 & 4 & 25 & 3 & 23 & 4 & 18 & 4 & 20 & 23 & 22 & & & & & & & 17 & 1 & 26 & 0.2 \\
\hline in & 12.3 & & 11.5 & $5 \quad 1.0$ & 11. & 1.5 & 11. & 31.4 & 8. & 32.0 & 3.9 & 51.3 & 9.0 & 6.5 & 10.0 & & & & & & & 5.8 & 0.2 & 11.5 & 0.5 \\
\hline $\bar{v}$ & 3.0 & 0.5 & 3.5 & $5 \quad 1+0$ & 3. & 0.7 & 4. & 31.5 & 5. & 2.5 & \begin{tabular}{|l|l}
10.1 \\
\end{tabular} & 4.2 & 5.3 & 4.2 & 4.0 & & & & & & & 2.1 & 0.1 & 2.5 & 0.2 \\
\hline LA. & 76 & 13 & 96 & ${ }^{23}$ & 76 & 10 & 90 & 11 & 95 & 25 & 112 & 65 & 80 & 89 & 94 & & & & & & & 52 & 7 & 128 & 16 \\
\hline$F$ & 645 & in & 699 & 319 & 57 & 70 & \begin{tabular}{|l|l|}
6991 \\
\end{tabular} & 98 & 793 & 194 & 142 & 377 & 1003 & 353 & 650 & & & & & & & 322 & 21 & 695 & 46 \\
\hline 8 & 26 & 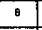 & 24 & 16 & 27 & $\begin{array}{l}6 \\
\end{array}$ & 30 & 6 & 34 & 23 & 26 & 5 & 30 & 37 & 25 & & & & & & & 25 & 3 & 23 & 6 \\
\hline NS & 0.6 & 7.2 & & 85.7 & 2. & 0.9 & 2. & $2 \quad 1$. & & $7 \quad 3.6$ & & 7.5 & $6-5$ & 3.9 & 4.4 & & & & & & & 2.1 & 0.2 & 2.7 & 0.2 \\
\hline $\mathrm{Nu}^{*}$ & 6 & 5 & 9 & 16 & 7 & 6 & 10 & 11 & 12 & 10 & 19 & 20 & 12 & 7 & 20 & & & & & & & 14 & 1 & 1 & 1 \\
\hline Sn & 5 & 3 & 8 & 10 & 7 & 4 & 10 & 3 & 12 & 5 & 21 & 10 & 19 & 10 & 13 & "11 & 3 & 16 & 3 & 24 & 13 & 5 & 3 & 14 & 3 \\
\hline$y$ & 1 & 0.5 & 1 & 7.2 & , & 0 & 2 & 1.1 & 8 & 1.9 & 3 & 2.3 & 4 & 11 & 1 & & & & & & & i & 0.3 & 1 & 0.3 \\
\hline cu & 1 & 3 & 4 & 5 & 1 & 2 & 1 & 3 & 0 & $!$ & 1 & 2 & 1 & $T$ & 2 & & & & & & & 3 & 2 & ' & 2 \\
\hline $\mathrm{pb}$ & 23 & 6 & \begin{tabular}{|l|}
23 \\
\end{tabular} & 3 & 27 & 9 & 26 & 15 & 21 & 3 & 20 & 5 & 21 & 19 & 16 & & & & & & & 10 & 2 & 22 & 4 \\
\hline $2 n$ & 70 & 12 & 66 & 15 & 64 & 27 & 77 & 43 & 51 & 15 & 43 & 18 & 55 & 57 & 58 & 69 & 8 & 60 & 10 & 50 & 16 & 42 & 2 & 68 & 3 \\
\hline
\end{tabular}

hypersthene, ilmenite, hematite and rutile decrease in this zone. These variations are consistent with normal zoning (1.e., increase in the degree of differentiation toward the core of the pluton). In the inner portion of the HP the transition from unit 3 to units $4 a$ and 4 displays a reversal of the above trend with decreasing $\mathrm{SiO}_{2}$ (72.95-71.33\%) and increasing $\mathrm{TiO}_{2}(0.20-0.40 \%), \mathrm{AI}_{2} \mathrm{O}_{3}(14.32-14.49 \%)$, $\mathrm{Fe} \mathrm{O}$ (2.09-2.94\%), MnO (0.05-0.06\%), MgO (0.77$1.04 \%$ and $\mathrm{CaO}(0.64-1.07 \%)$. This is accompanied by a decrease in normative quartz, orthoclase. corundum and TTDI and increasing normative anorthite, enstatite, hypersthene, hematite and rutile. These trends are consistent with reverse zoning near the core of the HP.

With the exception of unit $5 b$, all rocks in sequence $B$ are more evolved than those of sequence
A. Sequence $B$ rocks have higher $\mathrm{SiO}_{2}$, normative quartz, corundum, apatite and TTDI and lower $\mathrm{TiO}_{2}$, $\mathrm{Al}_{2} \mathrm{O}_{3}, \mathrm{Fe}_{2} \mathrm{O}_{3}$, $\mathrm{MgO}$ and $\mathrm{CaO}$ and normatibe anorthite, 2 (thstatite, ilmenite, hematite, hypersthene and rutile than the majority of sequence A rocks. Conversely, unit $5 \mathrm{~b}$ is more primitive than the rest of sequence $B$ rocks and has major element contents and normative mineralogy which is intermediate between units 3 and 4 . The implications of this will be discussed later.

Rocks from this study were compared with rocks of similar composition from the central part of the SMB (McKenzie and Clarke, 1975) as determined by the TTDI. Granodiorite, adamellite and leucogranite from the central SMB (TTDI- 82.59, 93.85, 95.91, respectively) were compared with units 1,3 , and $5 a, c$ (TTDI $=83.21,93.42,96.34$, 
respective1y) from this study. Several major elements and normative compositions are similar for the HP and central SMB; however, the HP is enriched in $\mathrm{MgO}, \mathrm{P}_{2} \mathrm{O}_{5}$ and normative corundum, enstatite, hypersthene and apatite and depleted in normative anorthite. These geochemical differences have been noted previously by MacDonald and Clarke (1985) who concluded that the MB, HP and indeed most of the eastern Meguma granitold rocks display similar geochemical characteristics.

Smith (1979) conducted a similar geochemical comparison between the HP and two plutonic centres in the central SMB and noted statistical differences between the individual plutons. However, as stated above, the rock classification scheme used by Smith (1979) was much less definitive than that of this study. For example, Smith's (1979) "granodiorite" ( $\mathrm{S}_{0}$ - 69.27\%) consists of units $1,2 \mathrm{a}$, and $2 \mathrm{~b}\left(\mathrm{SHO}_{2}-68.11,69.30\right.$ and 69.80 , respectively) of this study, whereas his "biotite granite" unit ( $\left.\mathrm{S}_{10}-73.09\right)$ consists of units $2 \mathrm{~b}, 3$, and $4\left(\mathrm{StO}_{2}-69.80,72.95\right.$ and 71.33 , respective1y) in our study. Therefore, Smith (1979) was not necessarily comparing similar rock types from different localities within the SMB.

\section{Trace Elements}

To facilitate discussion, the trace elements have been grouped into "compatible" and "Incompatible" elements. Thus, with respect to the present study "compatible" elements should show a depletion commensurate with progressive differentiation, whereas "Incompatible" elements will show enrichment trends. Certain elements display strong compatible/incompatible trends whereas others display much weaker trends.

The transition from the margin to the core of the zoned sequence (A) is marked by an initial decrease in the compatible elements ( $\mathrm{Sc}, \mathrm{Ba}, \mathrm{La}, \mathrm{Hf}, \mathrm{Th}, \mathrm{Sr}$, $\mathrm{Y}, \mathrm{Zr}$ and $\mathrm{V})$ and a concomitant increase in the incompatible elements ( $U, \mathrm{Rb}, \mathrm{Ta}, \mathrm{W}$ and $\mathrm{Sn}$ ) from unit 1 through units $2 a$ and $2 b$ to unit 3 (e.g.. Figs. $3 a$ to $3 f$ ). These trends indicate normal zoning in the outer section of the HP. From unit 3 to the core of the pluton (1.e.. unit 4) there is a slight reversal in all trends, with increasing compatible elements and decreasing incompatible elements (e.g.. Figs. 3a to 3f). These data agree with the observed reversal in petrographic and major element trends and suggest reverse zoning in the central regions of the HP.

To graphically represent the nature of the zoning in the HP, an idealized cross section through the sequence has been prepared (F1g. 4). Locations for the 22 samples are given in Figure 2. The relative position of each sample was projected onto a central 1ine. Figure 4 presents cross sections for $\mathrm{Zr}, \mathrm{Rb}$, Th, $U$, and La; these elements were chosen because they show some of the smoothest trends and maximum variations. An "average" line linking points has been visually estimated to represent the overall trends. Average compositions and standard deviations from Table 2 are also plotted for each unit and indicate that the analyses used in Figure 4 are representative of their respective units. All five elements indicate normal zoning near the margins of the sequence with decreasing $\mathrm{Zr}, \mathrm{Th}$ and $\mathrm{La}$ and increasing $\mathrm{U}$ and $\mathrm{Rb}$ from unit 1 to units $2 a, 2 b$, and 3 . Conversely there is a slight, yet consistent, reversal of the geochemical zoning from unit 3 to $4 a$ and 4 with increasing $\mathrm{Zr}$. Th, and $\mathrm{La}$ and decreasing $\mathrm{U}$ and $\mathrm{Rb}$.

Contoured plots for $\mathrm{Zr}$ and La were prepared using 87 samples from the zoned sequence $(A)$ and are presented in Figures 5a and 5b. Both elements show remarkably consistent patterns throughout the HP. The geological boundaries have not been included in Figure 5; however, it is apparent that the highest contents of $\mathrm{Zr}$ and $\mathrm{La}$ are near the perimeter of the HP (1.e., near units $1,2 a$, and $2 b$ ) and rap1d1y decrease 1nward as expressed by closely spaced contours. Both elements continue to decrease in the western HP (1.e.. over unit 3 ) whereas they increase in the eastern HP (1.e., over units $4 \mathrm{a}$ and 4), as shown in the cross section in Figure 4. These data indicate that reverse zoning is present in the eastern HP whereas the western HP is normally zoned.

The majority of rocks in sequence $B$ (1.e.. units $5 a, 5 b$, and 6) are geochemically more differentiated than those in sequence $A$, with lower concentrations of compatible elements and elevated levels of incompatible elements. However, unit $5 \mathrm{~b}$ rocks contain slightly higher compatible element and lower incompatible element contents than the average compositions of unit 3 which it clearly postdates from field data. The implications of this will be discussed below.

\section{DISCUSSION}

A11 previous workers have concluded that the major factor controlling the composition of the varlous rocks in the SMB was fractional crystallization with the progressive removal of blotite (and included accessories) and plagioclase followed by alkall feldspar and quartz (Smith, 1974. 1979: McKenzie and Clarke, 1975; Clarke and Muecke, 1985). The progressive decrease in biotite and plagloclase (Table 1) and the "smooth" geochemical trends (Figs. 3, 4) displayed by the rocks in this study suggests that fractional crystallization was an important factor. For example, the outer, normally zoned segment of the HP may represent sidewall fractional crystallization or accretion as suggested by Smith (1979). The core of the pluton (1.e., unit 4), however, is clearly not a differentiate of the surrounding rocks (1.e.. unit 3 ) and, therefore, must be explained by an alternative mechanism.

Baker and McB1rney (1985) proposed a model for the formation of zoned magma chambers which involves the following processes: (1) sidewall fractional crystallization along the $c 001$ walls of the magma chamber; (2) the creation of a fractionated (highly evolved) "boundary layer" which forms at the interface between the cooling "rind" and the pristine magma in the core of the chamber. The existence of this boundary layer is dependant upon sluggish diffusion rates within the magma; (3) in granitoid systems this boundary layer w111 be less dense than the magma at the core of the chamber and will, therefore, rise to apical parts of the chamber and thus provide a mechanism for vertical stratification. This model avolds the problems associated with crystal settling in very viscous magmas as outlined by Rice (1981). Baker and McBirney (1985) have also shown that thermal (soret) diffusion, as outlined by Hildreth (1981), 

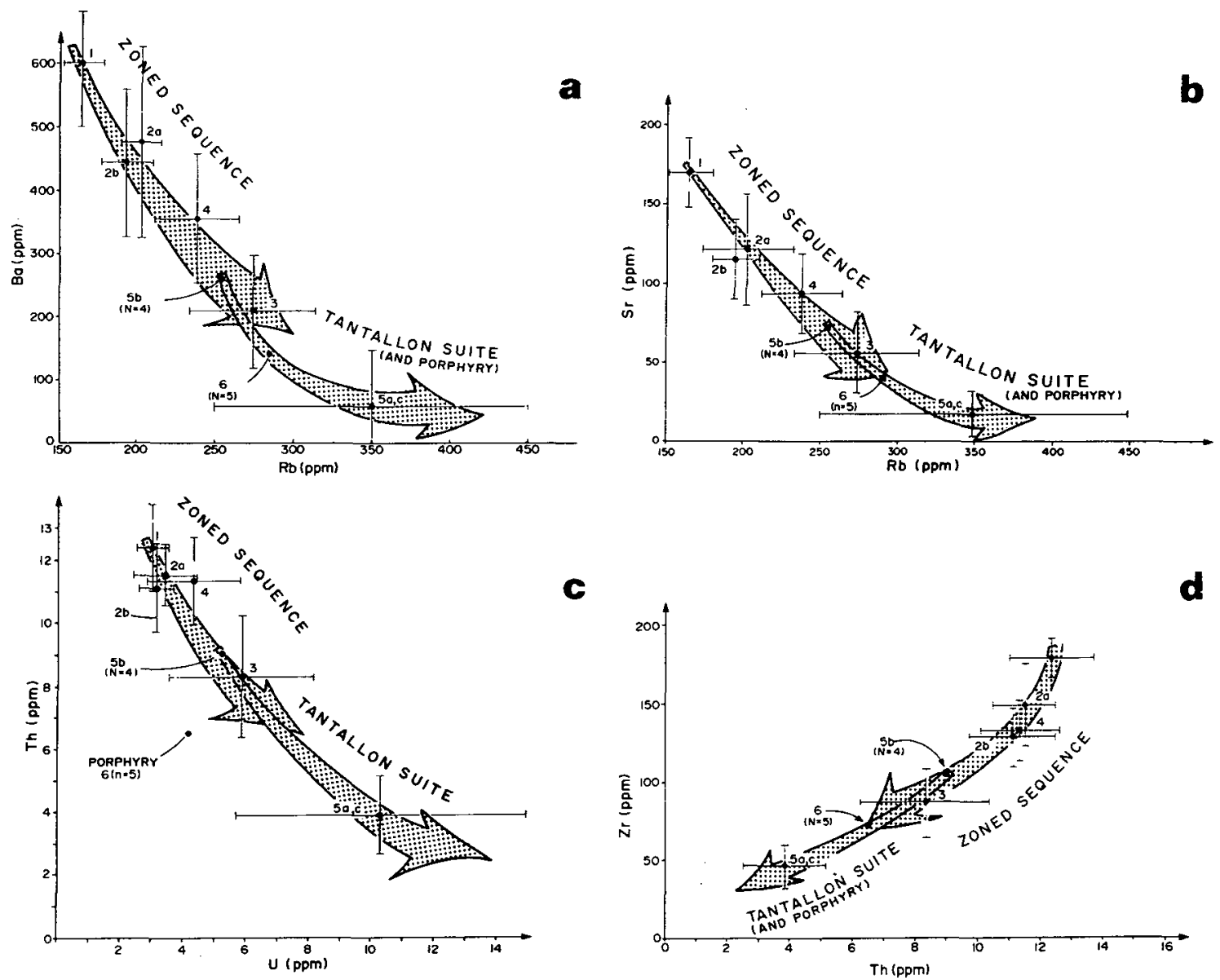

C
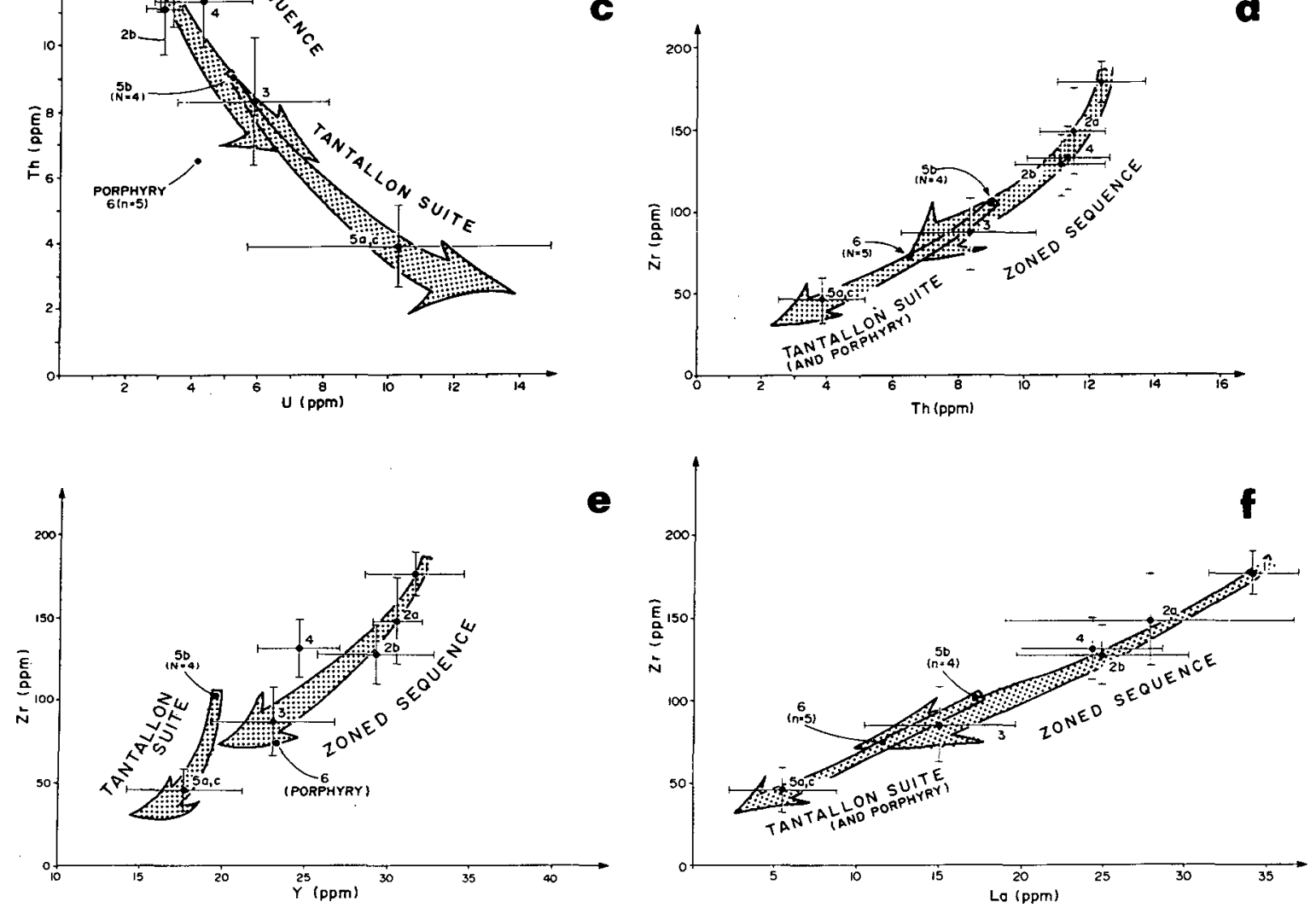

F1g. 3. Selected trace element variations which show the range of compositions in both the zoned sequence $A$ and the late-stage sequence B (1.e., Tantallon sulte and porphyry). F1gures 3a, b, and c show the compatible nature of Ba, Sr, and $T h$ compared to the incompatible nature of $\mathrm{Rb}$ and $\mathrm{U}$. Figures $3 \mathrm{~d}, \mathrm{e}$, and $f$ show the compatible nature and smooth trends of $\mathrm{Th}, \mathrm{Y}$, and La versus $\mathrm{Zr}$. This suggests the progressive removal of these elements in accessory phases. The reverse zonation of the HP is displayed by the primitive nature of unit 4 compared to the surrounding unit 3 .

is not a feasible mechanism for developing largescale stratification within magma chambers.

A reversely zoned pluton in Maine has recently been studied by Ayuso (1986). On the basis of geochemical and petrological evidence the compositional reversal was explained by the upwelling of a lower, more mafic part of a stratified sequence into the core of the pluton during emplacement. Bourne and Danis (1987), in trying to explain a reversely zoned, quartz monzodiorite-1eucomonzogranite complex in Quebec, invoked a two-stage model to explain the zoning. These authors envisaged first the development of a lower magma chamber which through sidewaj.1 fractional crystallization became vertically stratified, subsequently a "leaky" roof-zone enabled successively less evolved me1t to escape and formed an upper, reverse1y zoned pluton.

By combining the models from Ayuso (1986), Baker and McBirney (1985) and Bourne and Danis (1987) a 


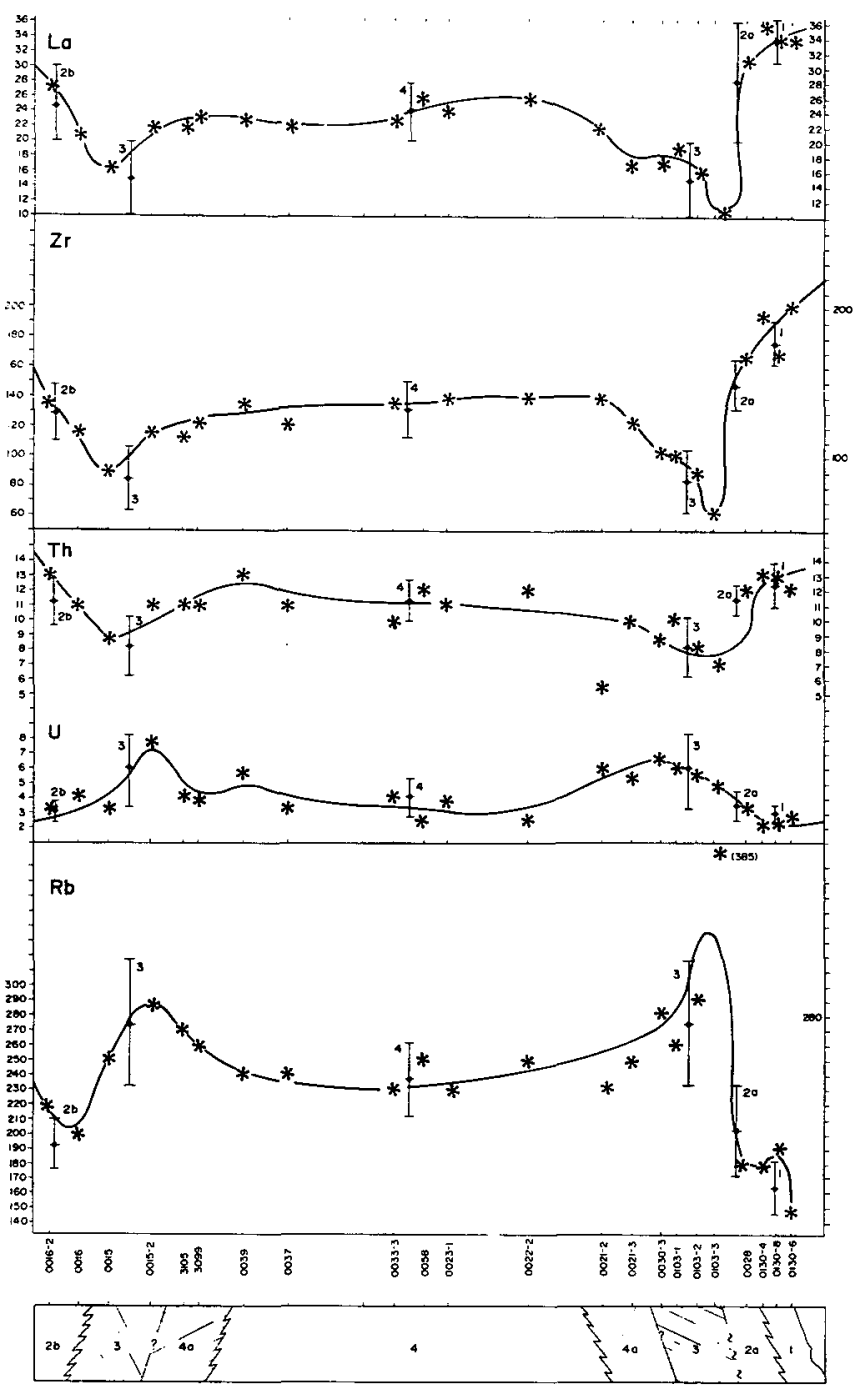

F1g. 4. Geochemical traverses across the zoned pluton for $\mathrm{Rb}, \mathrm{U}$. $\mathrm{Th}, \mathrm{Zr}$, and La. Note the reversal of the geochemical trends over the core of the pluton.

model for the rocks of the HP has been developed (Fig. 6). The first stage in this model envolves sidewall fractional crystallization which was initiated along the cool (metasedimentary) walls of the magma chamber. The first unit to crystallize was unit 1 (i.e., biotite granodiorite), this was subsequently followed by units $2 a$ and $2 b$ (1.e., biotite monzogranite). The observed gradational contact between these units is consistent with this suggestion. A highly evolved boundary layer then developed at the interface between unit $2(a+b)$ and the interior magma. This layer then ascended and gave rise to a vertically stratified magma chamber (Fig. 6). In this sequence unit 3 represents the most evolved material at the roof and unit 4 the most primitive magma. Unit $4 a$, which is the cordierite-rich zone, represents a horizontal transition layer between units 3 and 4 . Subsequent injection (upwelling) of magma into the lower parts of the chamber forces the layers to "warp" upwards. The maximum upwelling occurred in the eastern portion of the HP. Erosion to the present level
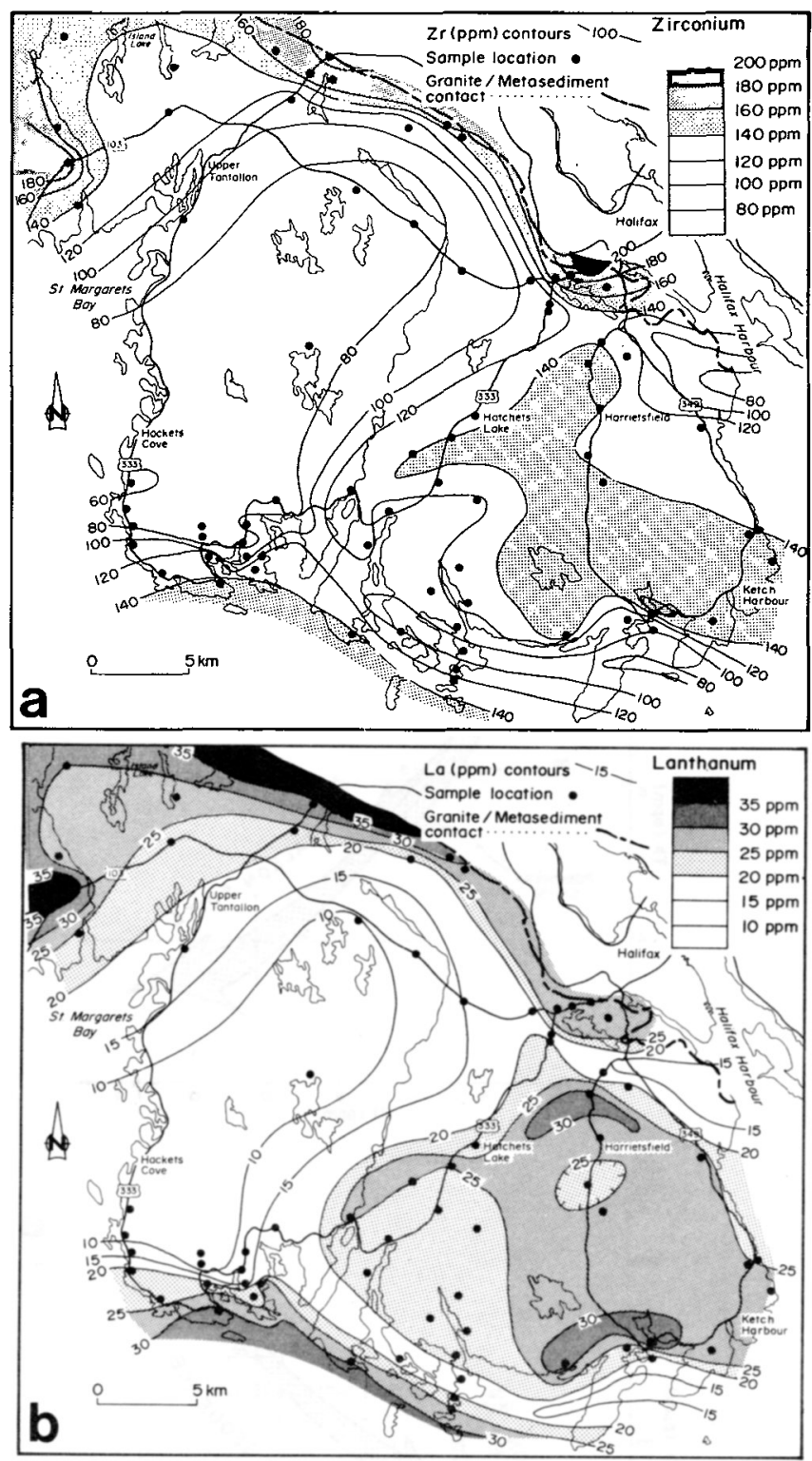

Fig. 5. Contoured plots of $\mathrm{Zr}$ (5a) and $\mathrm{La}$ (5b) for 87 samples from the zoned sequence (A). Note the normal zoning trends in the western HP and along the margins of the $\mathrm{HP}$ which are reversed over the eastern $\mathrm{HP}$.

(Fig. 6) then produced the observed outcrop pattern (Fig. 2).

One of the most notable 'marker' horizons in the zoned sequence is the cordierite-rich zone ( $4 a$ and adjoining areas of unit 3 ). This zone does not have an elevated content of xenolithic material, nor is it adjacent to the metasedimentary rocks. Therefore, a purely xenocrystic origin for cordierite, as outlined in Maillet and Clarke (1985), is not applicable for this zone. The authors feel that cordierite reflects a critical composition in the magma which presumably occurred at a distinct 'stratigraphic' zone in the magma chamber (Fig. 6). This interpretation is in accord with the findings of Cocker (1976) who concluded that the crystallization of cordierite in granitic rocks is dependant upon a critical $\mathrm{Fe} / \mathrm{Mg}$ ratio and 


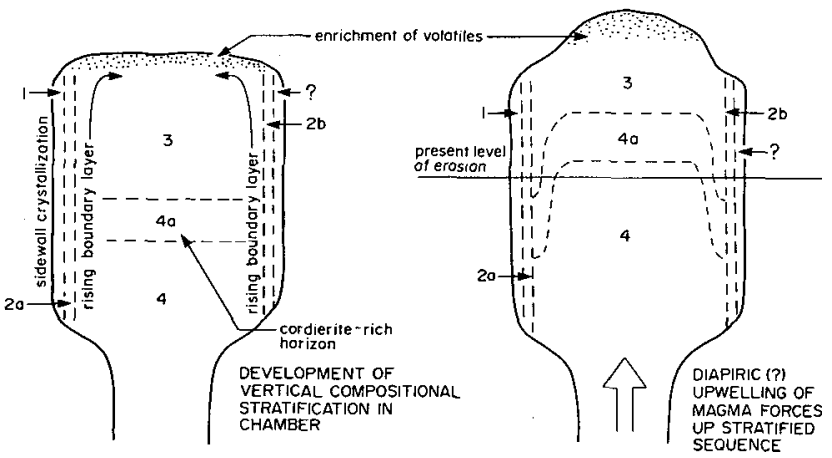

Fig. 6. A model for the formation of the zonation in the pluton. Crystallization commences along the cool metasedimentary walls (sidewall crystallization) followed by the rising of a fractionated boundary layer which causes vertical stratification of the central magma. Cordierite crystallizes in a discrete compositional layer in the sequence. Subsequent influx of magma into the lower part of the magma chamber "warps" the stratified sequence which, after erosion to present leve1, flelds the observed outcrop pattern (1.e., Fig. 2).

amount of alumina oversaturation in the me1t.

Unit 3, which is closest to the roof of the chamber, is the most texturally heterogeneous and pervasively altered unit in the zoned sequence. This may be explained by increased interaction with fluid phases which migrated towards the roof of the magma chamber (along with the rising boundary layer ?) and caused deuteric alteration effects such as "patch" perthite. The decrease in deuteric alteration and increased textural homogeneity from unit 3 to units $4 a$ and 4 reflects the decreased interaction with hydrothermal fluids at deeper levels in the chamber.

Although more rigorous quantitative modelling is required to unequivocally exclude other petrogenetic processes such as TGD (e.g., Hildreth, 1981; Ludington, 1981), we feel that the crystal dominated processes were likely the most influential (e.g., Miller and Mittlefehldt, 1984).

The HP appears to be unique in the eastern SMB in that it contains substantially higher $\mathrm{MgO}, \mathrm{P}_{2} \mathrm{O}_{5}$ and normative corundum, enstatite, hypersthene, apatite, and lower normative anorthite than rocks with similar Thornton Tuttle Differentiation Indices from the central part of the SMB (McKenzie and Clarke, 1975). Compositions are more similar to the MB (MacDonald and Clarke, 1985), which becomes part of the SMB in the reconstruction of Giles (1985) (Fig. 1). The fact that the HP differs from the other monzogranite plutons in the SMB, and appears to have its own crystallization history, supports the suggestion of Smith (1979) that the SMB is composite in nature and represents the coalescing of individual plutonic bodies.

Fractional crystallization has also been used to explain the evolution of late-stage rocks in the SMB (Smith, 1974; McKenzie and Clarke, 1975). Sequence B rocks ( $1 . e$. units $5 a, 5 c$, and 6 ) are predominantly more geochemically and petrologically evolved (1.e., more fractionated) than their host rocks. However, unit $5 \mathrm{~b}$ is slightly more primitive than and intruded into unit 3 (the most evolved rock of sequence $A$ ), which indicates that fractionation from unit 3 would be difficult. Although far from conclusive, this implies that sequences $A$ and $B$ represent two separate intrusive pulses which contradicts a single pulse, comagmatic history for the SMB.

Plots of $\mathrm{La}, \mathrm{Y}$ and $\mathrm{Th}$ versus $\mathrm{Zr}$ for this study are presented in Figures $3 \mathrm{~d}, 3 \mathrm{e}$, and $3 \mathrm{f}$. Progressive and consistent depletion of Th, La, Y and $\mathrm{Zr}$ occurs with progressive differentiation. Trends are very smooth and standard deviations (1.e., the bars in Fig. 3) are similar or even lower in the most evolved rocks (e.g., units $5 a$ and $5 c)$ when compared to the most primitive rocks (e.g., unit 1). Removal of these elements by fluid stripping would produce erratic results as the degree of removal would be proportional to the amount of alteration. This in turn would produce higher standard deviations in the most depleted rocks. Therefore, it is $11 k e 1 y$ that the above elements were all progressively removed via accessory mineral phases such as zircon, monazite and xenotime; the presence of these latter two has recently been confirmed by electron microprobe analysis. The fractionation of monazite would also explain the light REE depletion in the HP, as outlined in Smith et al. (1986). This contrasts with the findings of Muecke and Clarke (1981) and MacDonald and Clarke (1985) who concluded that Th and REE were removed via a fluid phase by fluorine complexing.

\section{CONCLUSIONS}

Evidence presented in this paper indicates that the HP evolved as a discrete plutonic body within the SMB. The HP is characteristically enriched in $\mathrm{MgO}, \mathrm{P}_{2} \mathrm{O}_{5}$ and normative corundum. enstatite, hypersthene, and apatite and depleted in normative anorthite when compared with the central portion of the SMB. The high normative corundum and $\mathrm{MgO}$ contents are expressed as high modal amounts of cordierite. These features are similar to those reported in the MB by MacDonald and Clarke (1985).

Individual rock units of sequence $A$ define a symmetrically zoned pluton with both gradational and intrusive contacts between units. Petrographic and geochemical evidence indicates that the perimeter of sequence $A$ (i.e., units $1,2 a, 2 b$, and 3) is "normally" zoned, whereas these trends are reversed in the transition from unit 3 to unit 4. Thus, the core of the pluton is "reversely" zoned.

Fractional crystalization of predominantly biotite (and accessory zircon, monazite, xenotime and 11menite) and plagioclase can explain variations in the normally zoned perimeter of the pluton. The reversal in the core, however, may reflect an upwelling of lower layers in a stratified sequence similar to that of the Bottle Lake Complex in Maine (Ayuso, 1986).

Stratification within the HP was caused by a rising "boundary layer" of evolved melt into apical portions of the magma chamber, as suggested by Baker and McBirney (1985).

$A$ separate, late-stage suite (sequence $B$ ) intruded the zoned sequence $A$. The majority of sequence $B$ rocks are petrographically and geochemically more differentiated than those of sequence $A$. However, unit $5 \mathrm{~b}$ is slightly mor? primitive than the most evolved rocks of sequence $A$ (i.e., unit 3 which is intruded by unit $5 b$ ) suggesting that sequence $B$ may represent a second pulse of magma.

The observations reported in this paper have only 
been possible after detalled field and laboratory work. The zonation in the HP is subtle, occurring in rocks which are all essentlally medium - to coarse-grained and megacrystic, but which have slight, yet consistent variations in biotite, cordierite and muscovite contents. Similar zonation has been described in the Bottle Lake Complex Maine (Ayuso, 1986) and Lacorne Complex, Quebec (Bourne and Danis, 1987). Zoned plutons may be much more common in the Appalachian Orogen but their presence has not been widely recognized because of the lack of systematic mapping of granitic rocks.

\section{ACKNOWLEDGEMENTS}

Th1s research was funded by the 1984-89 CanadaNova Scotia Mineral Development Agreement. The authors were assisted in the fleld by S. Jewkes and G. Howe11s. The authors would like to thank their colleagues at the NSDME and especlally the rest of the South Mountain Batholith gang (SMEEBES) including M. Corey, L. Ham, P. Finck, M. Graves, G. 0 'Re1l1y and F. Boner. Special thanks are extended to D. Kontak for his motivational skills, editorlal prowess, and extensive knowledge of petrogenetic processes and to A.K. Chatterjee for his support and conception of the project.

AYUSO. R.A. 1986. Field relations, crystallization, and petrologg of reversely zoned granitic plutons in the Bottle Lake Complex, Malne. United States Geological Survey. Professional Paper 1320, $58 \mathrm{p}$.

BAKER, B.H. a and MCBIRNEY, A.R. 1985. L1quid fractionation, Part III. Geochemistry of zoned magmas and the effects of crystal fractionation. Journal of Volcanology and Geothermal Research, 24, pp. 55-81.

BELL. K.. and BLENKINSOP, J. 1960. Mississippian Horton Group of type Windsor-Horton district. Nova Scotia. Geological Survey of Canada, Memo1r 314,112 p.

BOURNB, J.. and DANIS. D. 1987. A proposed model for the formation of reversely zoned plutons based on a study of the Lacorne Complex. Superior Province, Quebec. Canadian Journal of Barth Sciences, 24. pp. 2506-2520.

CHAREST, M.H. FARLEY, E.J. and CLARKR, D.B. 1985. The northwestern part of the New Ross-Vaughan Complex: petrology. geochemistry and mineral deposits. In Guide to the Granites and Mineral Deposits of Southwestern Nova Scot1a. Edited by A.K. Chaterjee and D.B. Clarke. Nova Scot1a Department of Mines and Bnergy. Paper 85-3. pp. 29-40.

CHATTERJER, A.K., and MUBCKB G.K. 1982. Geochemistry and the distribution of uranium and thorium in the granitic rocks of the South Mountain Bathollth, Nova Scot1a: some genet1c and exploration Implications. In Uranium in Granites. Edited by Y.T. Maurice. Geological Survey of Canada. Paper 81-23. PP.

CLARKB, D.B., and HALLIDAY, A.N. 1980. Strontium 1sotope geologg of the South Mountain Bathol1th, Nova Scot1a. Geoch1mica et Cosmoch1mica Acta. 44. pp. 1045-1058.

CLARKB, D.B. . and MUECKE, G.K. 1980. Igneous and metamorph1c geologg of southern Nova Scot1a. Geological Association of Canada/Mineralogical Association of Canada (GAC/MAC) F1eld Gu1de 21, $101 \mathrm{p}$.

CLARKB. D.B.. and MUBCKE, G.K. 1985. Rev1ew of the petrochemistry and origin of the South Mountain Bathollth and assoclated plutons. Nova Scotia, Canada. In High Heat Production (HHP) Granites, Hydrothernal Circulation and Ore Genesis. Institution of Mining and Metallurgy. England, pp. 41-54.

COCKER. J.D. 1976. Garnet-cordierite granites formed by the partial meiting of continental crust. Geological Soclety of Amer1ca, Program with Abstracts, 8, p. 816.

CORMIER, R.F., and SMITH, T.E. 1973. Radiometric ages of granitic rocks, southwestern Nova Scot1a. Canadian Journal of Earth Sciences, 10, pp. 1201-1210.

ERMANOVICS. I.F. 1970. Zonal structure of the Perth Road Monzonite, Grenville Province. Ontar10. Canadian Journal of Earth Sciences, 7. pp. 414-434.

FAIRBAIRN, H.W.. HURLEY, P.M. an 87 PINSEN, W.H. 1964. Preliminary age study and 1nitial $\mathrm{Sr}^{87} / \mathrm{Sr}^{86}$ of Nova Scotla granitic rocks by the $\mathrm{Rb}-\mathrm{Sr}$ whole rock method.

Geological Society of America Bulletin, 75, pp. 253-258.

FARIBAULT, E.R. 1908. C1ty of Hallfax Sheet, Map No. 68. Geological Survey of Canada, Publication No. 1019.

GILES, P.S. 1985. A major Post-V1sean sinistral shear zone new perspectives on Devonian and Carboniferous rocks of southern Nova Scotia. In Guide to the Granites and Mineral Deposits of Southwestern Nova Scotia. Edited by A.K. Chaterjee and D.B. Clarke. Nova Scotia Department of Mines and Energy. Paper 85-3, pp. 233-248.

HALLIDAY, A.N. . STEPHENS, W.E. . and HARMON. R.S. 1980. Rb-Sr and 0 1sotopic relationships in 3 zoned Caledonian granitic plutons, southern uplands. Scotland; evidence for varled sources and hybridization of magmas. Journal of Geological Soc1ety of London. 137. pp. 329-348.

HALLIDAY, A.N., STEPHENS, W.E. . and HARMON, R.S. 1981. Isotopic and chemical constraints on the development of peraluminous Caledonian and Acadian granites. Canadian Mineralogist. 19, pp. 205-216.

HILDRETH. W. 1981. Gradients in silicic magma chambers: implications for 11thospheric magmatism. Journal of Geophys1cal Research, 86. pp. 10153-10192.

HOWIB, R.D. and BARSS, M.S. 1975. Upper Paleozolc rocks of the Atlantic Provinces, Gulf of St. Lawrence, and adjacent continental shelf. In Offshore Geology of Bastern Canada. Geological Survey of Canada. Paper 74-30. Volume 2. $258 \mathrm{p}$.

KARNER, F.R. 1968. Compositional varlation in the Tunk Lake granite pluton, southeastern Ma1ne. Geological Society of Amer1ca Bulletin, 79, pp. 193-221.

LONGSTAFFB, F.J.. SMITH, T.E. , and MUEHLENBACHS, K. 1980. Oxygen 1sotope evidence for the genesis of Upper Paleozoic granito1ds from southwestern Nova Scot1a. Canadian Journal of Earth Sc1ences, 17, pp. 132-141.

LUDINGTON, S. 1981. The Redskin Granite: evidence for thermogravitational diffusion in a Precambrian granite batholith. Journal of Geophysical Research, 86. pp. 1042310430 .

MAILLET, L.A., and CLARKB, D.B. 1985. Cordierite in the peraluminous granites of the Meguma Zone, Nova Scot1a. Canada. Mineralogical Magazine. 49. pp. 695-702.

MACDONALD. M.A. and CLARKB, D.B. 1985. The petrology. geochemistry and economic potential of the Musquodobolt Batholith, Nova Scotia. Canadian Journal of Earth Sciences. 22. pp. 1633-1642.

MACDONALD, M.A., COREY, M.C., HAM, L.J., and HORNB, R.J. 1987. The geologg of the South Mounta1n Bathol1th, NTS sheets $21 \mathrm{~A} / 09$, 21 $\mathrm{A} / 10,21 \mathrm{~A} / 15$ and $21 \mathrm{~A} / 16$ (west). In Mines and Minerals Branch, Report of Activities 1986. Edited by J.L. Bates and D.R. MacDonald. Nova Scotia Department of Mines and Energy, Report 87-1, Pp. 107-128.

MCKENZIE. C.B.. and CLARKB, D.B. 1975. Petrology of the South Mountain Batholith, Nova Scotia. Canadian Journal of Barth Sclences, 12, pp. 1209-1218.

MILLER, C.F., and MITTLEFEHLDT, D.W. 1984. Bxtreme fractionation in felsic magma chambers: a product of 11quid-state diffusion or fractional crystallization? Earth and Planetary Science Letters, 68. pp. 151-158.

MUECKR, G.K. and CLARKB, D.B. 1981. Geochemical evolution of the South Mounta1n Bathol1th, Nova Scot1a: rare-earth-element evidence. Canadian Mineralogist, 19, pp. 133-146.

REYYOLDS, P.H., ZENTILLI, M., and MUECKE, G.K. 1981. K-Ar and $\mathrm{Ar} /{ }^{39} \mathrm{Ar}$ geochronology of gran1told rocks from southern Nova Scot1a: 1ts bearing on the geological evolution of the Meguma Zone of the Appalachians. Canadian Journal of Earth Sc1ences, 18. pp. 386-394.

REYNOLDS, P.H., ELIAS, P., MUECKE, G.K., and GRIST, A.M. 1987. Thermal bofstorg of the southwestern Meguma Zone. Nova Scot1a, from an ${ }^{40} \mathrm{Ar} / 39 \mathrm{Ar}$ and fission track study of 1ntrusive rocks. Canadian Journal of Earth Sc1ences, 24. pp. 1952-1965.

RICE. A. 1981. Convective fractionation: a mechanism to provide cryptic zoning (macrosegregation) layering. crescumulates, banded tuffs and explosive volcanism in 1gneous processes. Journal of Geophysical Research. 86. pp. 405-417.

SMITH, T.E. 1974. The geochemistry of the granitic rocks of Hallfax County. Nova Scot1a. Canadian Journal of Earth Sc1ences, 11, pp. 650-656.

SMITH. T.E. 1975. Layered gran1t1c rocks at Chebucto Head, Halifax County. Nova Scotia. Canadian Journal of Earth Sciences, 12 , pp. 456-463.

SMITH, T.E. 1979. The geochemistry and origin of the Devonian granitic rocks of southwest Nova Scot1a. Geological Soc1ety of America Bullet1n. Part 2. 90, pp. 850-885.

SMITH, T.E., MILLER, P.M., and HUANG, C.H. 1982. Solidification and crystallization of a stanniferous granitoid pluton. Nova Scotia, Canada. In Metallization Associated with Ac1d Magmatism. Edited by A.M. Evans. John Wiley and Sons Limited. London, pp. 301-320.

SMITH. T.E. . PECK. D., HUANG, C.H., and HOLM, P.B. 1986. A re- 
appraisal of the alaskite/muscovite-blotite granite sulte of Halifax County. Nova Scotia. Maritime Sediments and Atlantic Geology, 22, pp. 101-116.
SMITH, T.E. and TUREK, A. 1976. T1n-bear1ng potent1al of some Devonian granitic rocks in southwest Nova Scot1a. Mineralium Deposita, 11, pp. 234-245. 